\title{
Joint restriction in an unhappy teenager
}

\author{
P J C Davis, J Hackett, K Johnson, J E McDonagh
}

Ann Rheum Dis 2005;64:1786-1787. doi: 10.1136/ard.2004.034934

A 14 year old girl presented with a year's history of joint pain, restriction, and swelling, initially diagnosed as juvenile idiopathic arthritis. She had no past medical problems but had given up her leisure pursuits owing to disability. Examination disclosed non-pitting oedema to midcalf; a woody texture of the soft tissues of the forearms and calves with fixed flexion deformities of her fingers, wrists, knees, and ankles due to the soft tissue changes, and normal overlying skin. Investigations showed the following results: normal muscle enzymes, eosinophilia of $1.7 \times 10^{9} /$ l, erythrocyte sedimentation rate $41 \mathrm{~mm} / \mathrm{lst} \mathrm{h}$, haemoglobin $112 \mathrm{~g} / \mathrm{l}$, negative autoantibodies, and normal complement levels. The differential diagnosis included eosinophilic fasciitis (EF) and scleroderma. At this time, the patient requested counselling as she had difficulty accepting an initial misdiagnosis, delayed correct diagnosis, and the uncertainty of the prognosis.

Magnetic resonance imaging (MRI) of the forearm was performed (fig 1). A biopsy showed chronic inflammatory changes in the deep subcutaneous fat and fascia with infiltration by lymphocytes, plasma cells, histiocytes, and eosinophils. The fascia was markedly thickened and fibrosed with focal fibrinoid necrosis, consistent with EF.

In view of her disability, she was treated with intravenous methylprednisolone ( $1 \mathrm{~g}$ /day for 3 days), then oral prednisolone $20 \mathrm{mg}$ daily $(0.3 \mathrm{mg} / \mathrm{kg} /$ day $)$ with normalisation of her erythrocyte sedimentation rate and eosinophilia. Methotrexate $15 \mathrm{mg}$ orally weekly was added 2 months later as there had been no further significant clinical response to steroids.

Five months later she improved functionally with reduced contractures despite prednisolone reduction to $12.5 \mathrm{mg}$ daily. A repeat MRI scan showed a reduction in the subcutaneous and fascial oedema, prompting a further reduction in steroids. At this time, she self harmed by cutting the skin of her forearms because of low mood, difficulties adjusting to her diagnosis, and the cosmetic side effects of steroids. She required treatment with antidepressants and counselling.

One year after diagnosis, an MRI scan showed persistent fascial oedema, leading to an increase in methotrexate

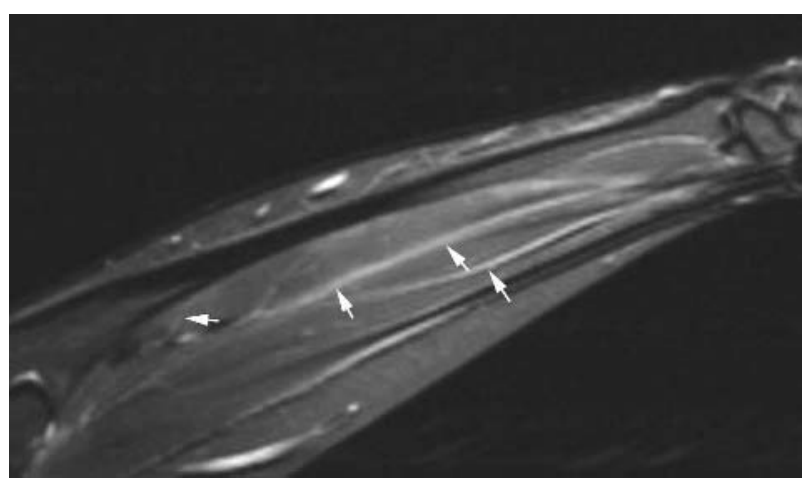

Figure 1 Coronal short $\tau$ inversion recovery (STIR) image of arm. The white arrows indicate areas of high signal oedema within the fascia.
(17.5 mg orally weekly) while maintaining her prednisolone at $3 \mathrm{mg}$ daily. Over the following 6 months finger movement improved despite stopping prednisolone in the interim. However, she attempted suicide by taking an overdose of methotrexate as she felt a burden to others, and required further psychological treatment.

Three years after diagnosis, she remains well and continues to receive methotrexate, with minimal inflammation on MRI, mild finger and wrist contractures, and return of full function. At no time has there been evidence of internal organ involvement.

EF is characterised by painful swelling and stiffness of the extremities, typically with thickened skin (peau d'orange), a peripheral eosinophilia, and characteristic histology. ${ }^{1-4}$ In contrast with adult EF, paediatric EF predominantly affects girls and has not been reported to cause haematological complications. In contrast with scleroderma, the epidermis and dermis are spared, whereas in comparison with polymyositis there is minimal muscle inflammation, distinctions illustrated by MRI. ${ }^{1-4}$

Teenage self harm is well recognised, particularly in girls, although may be underdiagnosed in those with a chronic illness. ${ }^{5}$ The impact of the disease itself, its impact upon body image and lifestyle, and the side effects of treatment, lack of predictability, and uncertainty of prognosis are all likely to contribute to mental health status during adolescence. ${ }^{6}$

Prognosis in paediatric EF remains uncertain, although a previous study has reported more favourable outcomes in older children. ${ }^{4}$ We expect to withdraw methotrexate from this girl within the next $12-18$ months if her signs and MRI appearance remains stable. This case highlights the use of MRI in assessment of soft tissue disease and in guiding drug management. Furthermore, the psychological impact during adolescence of a chronic disease, its management, and correct diagnosis should not be underestimated.

JEMCD is an Arthritis Research Campaign clinical senior lecturer.

\section{Authors' affiliations}

P J C Davis, J Hackett, Department of Rheumatology, Birmingham Children's Hospital, UK

K Johnson, Department of Radiology, Birmingham Children's Hospital, UK

J E McDonagh, Institute of Child Health, University of Birmingham, Birmingham, UK

Correspondence to: Dr J E McDonagh, Institute of Child Health, Birmingham Children's Hospital and University of Birmingham, Steelhouse Lane, Birmingham B4 6NH, UK; j.e.mcdonagh@bham.ac.uk

Accepted 23 April 2005

\section{REFERENCES}

1 De Clerck LS, Degryse HR, Wouters E, Van Offel JF, De Schepper AM, Martin JJ, et al. Magnetic resonance imaging in the evaluation of patients with eosinophilic fasciitis. J Rheumatol 1989;16:1270-3.

2 Liou CH, Huang GS, Taylor JAM, Juan CJ, Gao HW, Chen CY. Eosinophilic fasciitis in a military recruit: MRI evaluation with clinical correlation. Skeletal Radiol 2003;32:52-7. 
3 Cassidy JT, Petty RE. Textbook of pediatric rheumatology, 4th ed. Philadelphia: Saunders, 2001.

4 Farrington ML, Haas JE, Nazar-Stewart V, Mellins E. Eosinophilic fasciitis in children frequently progresses to scleroderma-like cutaneous fibrosis.

J Rheumatol 1993;20:128-32.
5 Hawton K, Rodham K, Evans E, Weatherall R. Deliberate self-harm in adolescents: self report survey in schools in England. BMJ 2002;325: 1207-11.

6 Suris JC, Michaud PA, Viner R. The adolescent with a chronic condition. Part I: Developmental isssues. Arch Dis Child 2004;8:938-42.

\title{
Relapse of autoimmune diseases after autologous $\mathrm{T}$ cell depleted stem cell transplantation may be triggered by $\mathrm{T}$ cells recently emigrated from the thymus
}

\author{
I Kötter*, T Daikeler*, H Einsele, S Koch, L Lochmann, L Kanz, J Löffler
}

Ann Rheum Dis 2005;64:1787-1789. doi: 10.1136/ard.2004.032870

$\mathrm{H}$ igh dose immunosuppressive therapy with subsequent autologous stem cell transplantation (ASCT) has proved effective for treatment resistant autoimmune diseases. ${ }^{1}$ However, in a number of patients, relapses of autoimmune disease after initial improvement or even remission occur. Until recently, it was impossible to differentiate recent thymic emigrants from residual or peripherally expanded $\mathrm{T}$ cells. Douek and coworkers ${ }^{2}$ and later our group ${ }^{3}$ described a method for detection of $\mathrm{T}$ cell receptor excision circles, stable DNA episomes which are formed during $\mathrm{T}$ cell receptor rearrangement in the thymus which are not replicated during mitosis, but are diluted during cell divisions. ${ }^{4}$ This study aimed at investigating whether these flares are associated with de novo $\mathrm{T}$ cell development.

Peripheral blood mononuclear cells were collected from six patients, mean age 32.5 years, range 24-42 (four with systemic sclerosis (SSc), one with Wegener's granulomatosis (WG), one with mutilating psoriatic arthritis (PsA)), after high dose immunosuppression with cyclophosphamide $50 \mathrm{mg} / \mathrm{kg}$ body weight plus anti-thymocyte globulin $20 \mathrm{mg} /$ $\mathrm{kg}$ on days 1-4, with subsequent retransfusion of $4.2 \times 10^{6}$ (median) CD34+ selected (by CliniMacs device) cells/kg body weight. Blood collection was performed at week 2 and then, at bimonthly intervals, genomic DNA was extracted using the QIAmp DNA Blood Mini Kit. DNA was stored at $-80^{\circ} \mathrm{C}$ until analysis. $\mathrm{T}$ cell receptor rearrangement excision circles
(TRECs) were measured by real time polymerase chain reaction using the light cycler (Roche Diagnostics Corporation, Idaho, USA). The study was approved by the local ethics committee and patients' informed consent obtained.

All patients improved considerably (all patients with SSc) or went into remission (PsA, WG) after ASCT. In all patients, previous immunosuppressive therapy was discontinued, except in the patient with WG, who still received ciclosporin A for her kidney transplant. Two patients relapsed after 7 , and 19 months, respectively (one SSc, one PsA). CD3+/CD4+ $\mathrm{T}$ cells were recovered after 6-14 months (median 12), and CD3+/CD8+ T cells a maximum of 3 months after ASCT in all patients. Autoantibodies disappeared in four of five patients after a median of 6 months and their recurrence or disappearance later did not correlate with relapse or remission. TRECs could not be detected in the patients shortly after ASCT (week 2), but recurred 9-26 months (median 16 months) after ASCT. In the two patients who experienced relapses, TRECs became detectable at the time when the first symptoms of relapse were noticed (SSc, patient No 3: relapse after 7 months, TRECs after 9 months; PsA, patient no 4: relapse after 19, TRECs after 21 monthsthe blood collection did not always coincide exactly with the diagnosis of relapse, which explains the 2 months' difference between diagnosis and first detection of TRECs) (fig 1 , table 1). $\downarrow$ TREC detection

Patient 1, WG

Patient 2, SSc

Patient 3, SSc

Patient 4, PsA

Patient 5, SSc

Patient 6, SSc

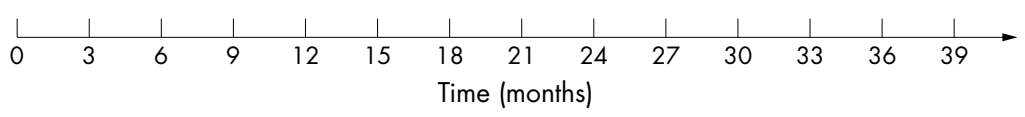

Figure 1 First detection of TRECs and relation to diagnosis of relapse. 


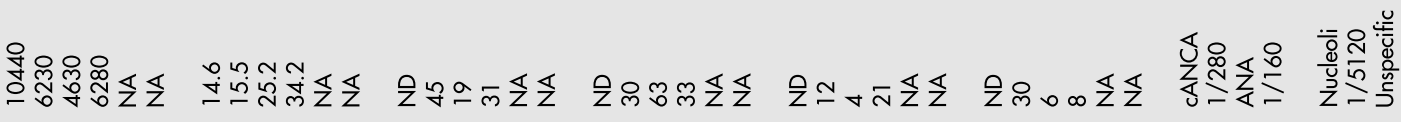

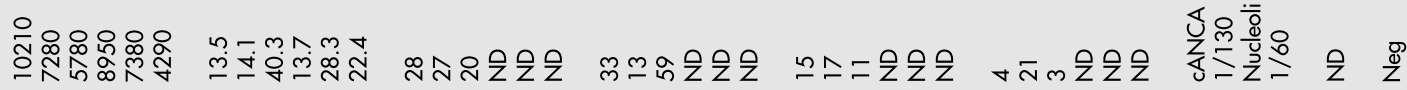

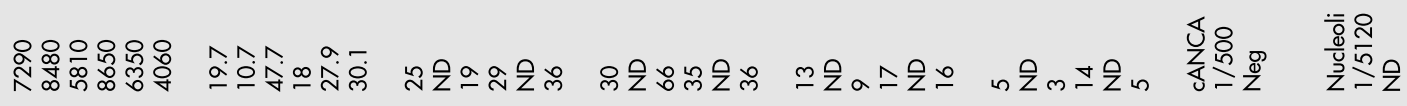

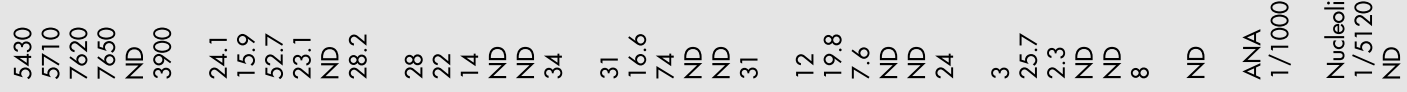

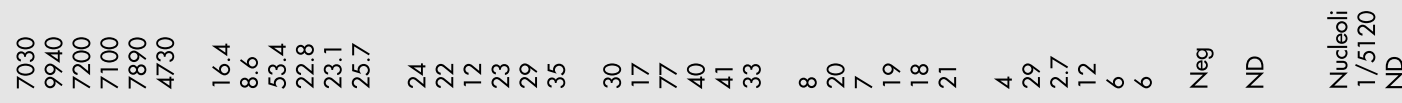

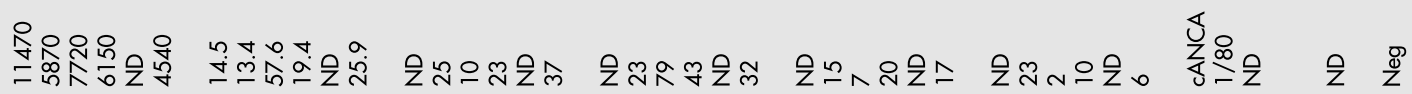

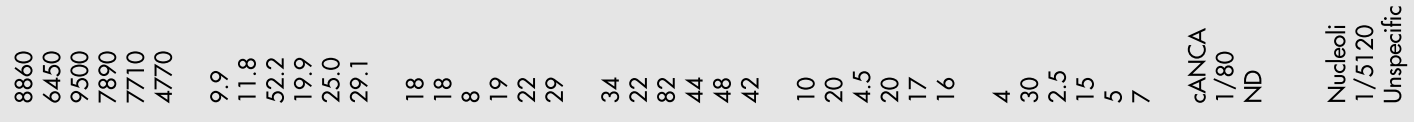

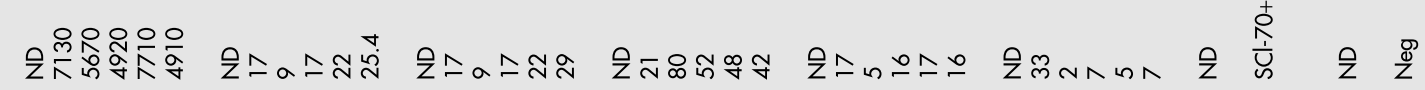

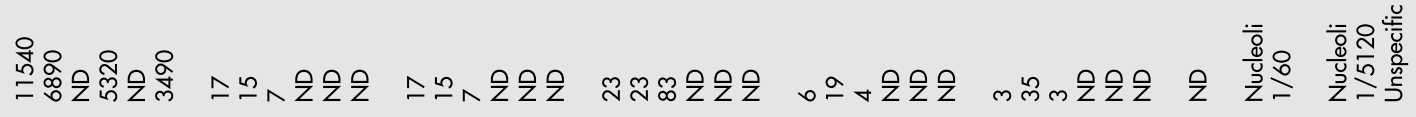

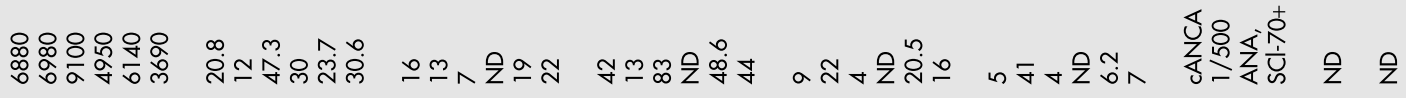

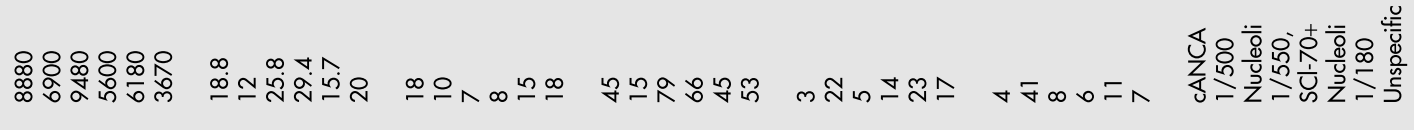




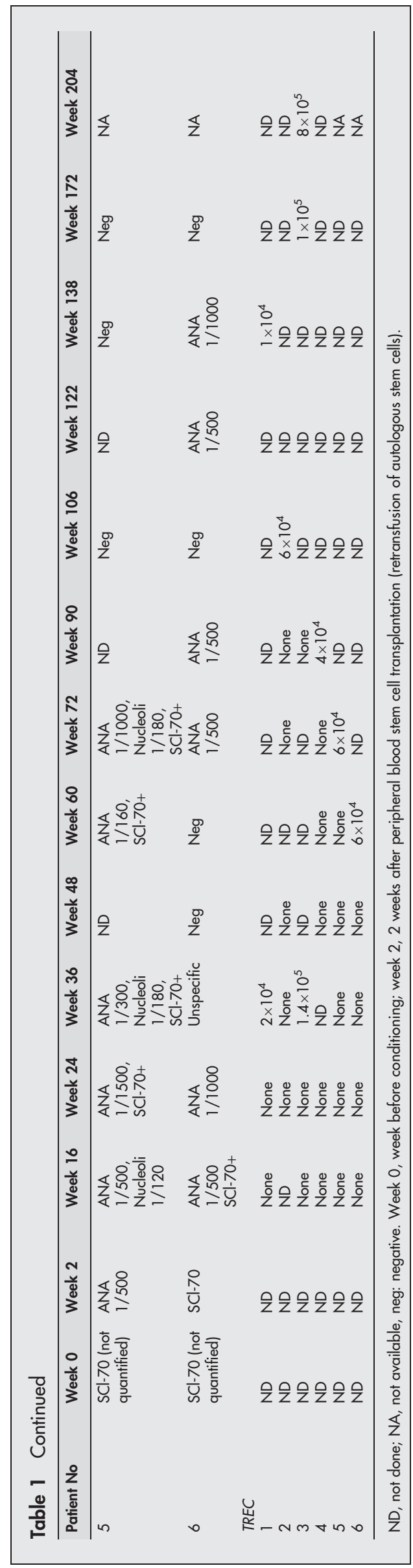

Normally, immune reconstitution and TREC recurrence is considerably quicker in ASCT than in allogeneic SCT. ${ }^{5}$ TREC recurrence in the allogeneic setting is known to be delayed by clinical events such as graft versus host disease, ${ }^{6}$ whereas in ASCT CD34+ selection of the graft was associated with increased thymic output ("rebound phenomenon"). ${ }^{2}$ In the present study, $\mathrm{T}$ cell ontogenesis was delayed even in comparison with allogeneic SCT for haematological diseases (TREC recurrence: 6 months ${ }^{6}$ ). Premature immunosenescence may be one of the reasons for this delay in $\mathrm{T}$ cell ontogenesis after ASCT in autoimmune diseases. ${ }^{78}$

De novo $\mathrm{T}$ cell ontogenesis in the thymus may be a critical event inducing relapses of the autoimmune disease, which may not be caused by peripheral expansion of memory T cells which survived the conditioning treatment, but by newly developed $\mathrm{T}$ cells of thymic origin. Vice versa, as in four patients TRECs recurred without relapse of the autoimmune disease, one might also argue that the occurrence of TRECs is not causally associated with relapse. Further studies of the immune reconstitution, correlating the recurrence of TRECs with $\mathrm{T}$ cell subsets, $\mathrm{T}$ cell receptor diversity, and autoantibody production in patients with autoimmune diseases after ASCT will improve our understanding of the pathogenesis of these diseases and help in the development of new therapeutic concepts.

\section{Authors' affiliations}

I Kötter, T Daikeler, H Einsele, S Koch, L Lochmann, L Kanz, J Löffler, Tübingen University, Hospital, Department of Internal Medicine II, Otfried-Müller-Str 10, D-72076 Tübingen, Germany

*The first and second authors contributed equally to this work.

Correspondence to: Dr I Kötter, ina.koetter@med.uni-tuebingen.de

Accepted 15 May 2005

\section{REFERENCES}

1 Tyndall A, Matucci-Cerinic M. Haematopoietic stem cell transplantation for the treatment of systemic sclerosis and other autoimmune disorders. Expert Opin Biol Ther 2003;3:1041-9.

2 Douek DC, Vescio RA, Betts MR, Brenchley JM, Hill BJ, Zhang L, et al. Assessment of thymic output in adults after haematopoietic stem-cell transplantation and prediction of T-cell reconstitution. Lancet 2000;355:1875-81.

3 Loeffler J, Baver R, Hebart H, Douek DC, Rauser G, Bader P, et al. Quantification of T-cell receptor excision circle DNA using fluorescence resonance energy transfer and the LightCycler system. J Immunol Methods 2002;271:167-75.

4 Hazenberg MD, Verschuren MC, Hamann D, Miedema F, van Dongen JJ. T cell receptor excision circles as markers for recent thymic emigrants: basic aspects, technical approach, and guidelines for interpretation. J Mol Med 2001;79:631-40.

5 Peggs KS, Mackinnon S. Immune reconstitution following haematopoietic stem cell transplantation. Br J Haematol 2004; 124:407-20.

6 Hazenberg MD, Otto SA, de Pauw ES, Roelofs H, Fibbe WE, Hamann D, et al. T-cell receptor excision circle and T-cell dynamics after allogeneic stem cell transplantation are related to clinical events. Blood 2002;99:3449-53.

7 Weyand CM, Fulbright JW, Goronzy JJ. Immunosenescence, autoimmunity, and rheumatoid arthritis. Exp Gerontol 2003;38:833-41.

8 Koetz K, Bryl E, Spickschen K, O'Fallon WM, Goronzy JJ, Weyand CM. T cell homeostasis in patients with rheumatoid arthritis. Proc Natl Acad Sci USA 2000;97:9203-8. 


\title{
Altered influenza virus haemagglutinin peptides inhibit $T$ cell responses to type II collagen in rheumatoid arthritis
}

\author{
L Xia, L Ru, L Zhanguo
}

Ann Rheum Dis 2005;64:1790-1791. doi: 10.1136/ard.2005.039305

$\mathrm{R}$ heumatoid arthritis (RA) is a T cell mediated autoimmune disease and associated with HLA-DR4 or HLADRl subtypes. ${ }^{12}$ Type II collagen (CII) has been implicated as an autoantigen of RA, and CD4+ $\mathrm{T}$ cell responses to CII or CII derived peptides are mainly presented by HLA-DR4/1 molecules. ${ }^{3}{ }^{4}$ Inhibition of antigen presentation by HLA-DR4/1 molecules can interfere with $\mathrm{T}$ cell mediated autoimmune responses in RA.

Our previous studies have suggested that altered CII263272 peptides inhibited CII263-272-induced T cell activation by blocking antigen presentation. ${ }^{56}$ In this study we examine the role of the altered influenza virus haemagglutinin (HA) 308-317 peptides (altered peptide ligands (APLs)) with single or multiple substitutions of $\mathrm{T}$ cell receptor (TCR) contact residues in $\mathrm{T}$ cell responses of peripheral blood mononuclear cells (PBMC) and inhibitory effects of APLs on CII263-272induced $\mathrm{T}$ cell activation in RA.

Twenty seven HLA-DR4/1 positive patients with RA (21 female, 6 male; mean (SD) age 53.6 (13.3) years; mean (SD) disease duration 10.4 (8.4) years) were included in the study. All patients fulfilled the American College of Rheumatology revised criteria for the classification of RA. Of 27 patients with RA, 24 (89\%) were positive for DR4 and 3 (11\%) for DRl.

Sequences of three APLs and CII263-272 were YVAQNTLKLA (APL1), YAKQATLKLA (APL2), YAKQATLALA

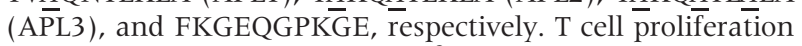
experiments were performed by $\left[{ }^{3} \mathrm{H}\right]$ thymidine incorporation assay. PBMC $\left(2.0 \times 10^{5} /\right.$ well $)$ were incubated with CII263-272 or APLs at $10 \mu \mathrm{g} / \mathrm{ml}$ for 5 days. In competitive studies, PBMC were preincubated with various concentrations of APLs as indicated for 2 hours before addition of CII263-272. Cultures were pulsed with $\left[{ }^{3} \mathrm{H}\right]$ thymidine $(0.25 \mu \mathrm{Ci} /$ well $)$ before the last 12 hours. The data are presented as the stimulation index (SI). Enzyme linked immunosorbent assay (ELISA) kits were

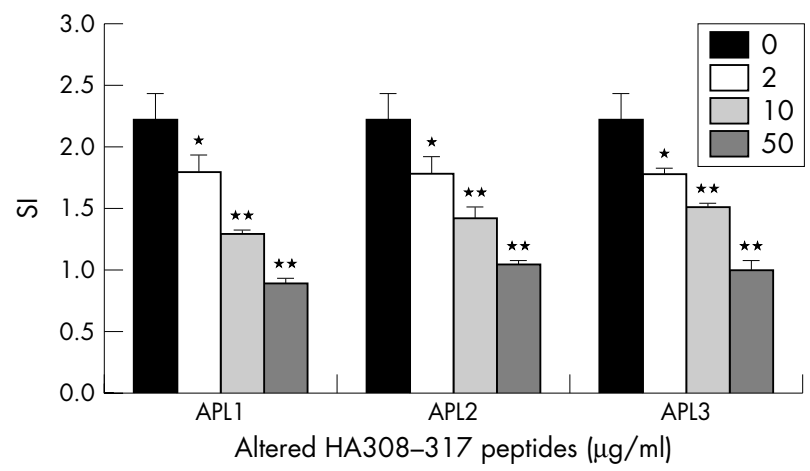

Figure 1 Inhibitory effects of altered HA308-317 peptides on T cell responses to CII263-272. PBMC from patients with RA were cultured for 5 days in the presence of $10 \mu \mathrm{g} / \mathrm{ml} \mathrm{Cll263-272} \mathrm{and} \mathrm{different}$ concentrations of altered HA308-317 peptides $(0,2,10$, and $50 \mu \mathrm{g} /$ $\mathrm{ml}$, respectively). Results showed that altered HA308-317 peptides suppressed T cell responses to Cll263-272 in a range from $2 \mu \mathrm{g} / \mathrm{ml}$ to $50 \mu \mathrm{g} / \mathrm{ml}\left({ }^{*} \mathrm{p}<0.05,{ }^{* *} \mathrm{p}<0.01\right)$.

Table 1 IFN $\gamma$ and IL4 production by PBMC of RA stimulated by altered $\mathrm{HA} 308-317$ peptides

\begin{tabular}{lll}
\hline $\begin{array}{l}\text { Stimulators } \\
(10 \mu \mathrm{g} / \mathrm{ml})\end{array}$ & $\begin{array}{l}\text { IFN } \gamma(\mathrm{pg} / \mathrm{ml}) \\
(\mathbf{n}=10)\end{array}$ & $\begin{array}{l}\text { IL4 }(\mathbf{p g} / \mathrm{ml}) \\
(\mathbf{n}=10)\end{array}$ \\
\hline Medium & $32.1(15.8)^{*}$ & $25.9(3.5)$ \\
CII263-272 & $77.3(60.8)$ & $28.1(4.9)$ \\
APL1 & $37.8(14.1)^{*}$ & $26.5(5.1)$ \\
APL2 & $37.1(23.5)^{*}$ & $29.6(4.0)$ \\
APL3 & $34.8(19.0)^{*}$ & $28.9(6.9)$ \\
\hline
\end{tabular}

Results are shown as mean (SD).

To find whether the altered HA308-317 peptides affected cytokine profile, supernatants of PBMC were evaluated for IFN $\gamma$ or IL4 production from 10 patients with RA with the altered HA308-317 peptides or CII263-272 stimulation. The levels of IFN $\gamma$ in the supernatants from PBMC stimulated with CII263-272 were significantly higher than those incubated with medium alone( $\left.{ }^{*} p<0.05\right)$. In contrast, aPL down regulated IFN $\gamma$ production in the supernatants from PBMC, compared with CII263$272\left({ }^{*} p<0.05\right)$. No differences of IL 4 productions in the supernatants were found when T cells in PBMC from patients with RA were stimulated with CII263-272 or APLs.

used to detect the levels of interferon $\gamma(\mathrm{IFN} \gamma)$ or interleukin (IL) 4 in the supernatants.

$\mathrm{T}$ cell proliferative responses to APLs in PBMC from RA were $7.4 \%$ for APL1, 3.7\% for APL2 or APL3, which were lower than for CII263-272 (62.2\%). The mean (SD) SI values for T cell responses to APLs were 1.2 (0.4) for APLl, $1.3(0.4)$ for APL2, and 1.1 (0.4) for APL3, which were significantly lower than for CII263-272 $(2.0(0.8))$. In addition, it was shown that $\mathrm{T}$ cell proliferative responses to CII263-272 were suppressed by APLs in a dose dependent manner in a range from $2.0 \mu \mathrm{g} / \mathrm{ml}$ to $50 \mu \mathrm{g} / \mathrm{ml}$ (fig l).

The levels of IFN $\gamma$ were significantly increased when stimulated with CII263-272 (77.3 (60.8) pg/ml), compared with the levels of 37.8 (14.1) pg/ml for APLl, 37.1 (23.5) pg/ $\mathrm{ml}$ for APL2, and 34.8 (19.0) $\mathrm{pg} / \mathrm{ml}$ for APL3, which were similar to the level for unstimulated control (32.1 (15.8) pg/ $\mathrm{ml}$ ). No significant differences were found in IL4 production when PBMC were stimulated with APLs or CII263-272 (table 1).

In this study we assessed $\mathrm{T}$ cell responses to APLs in patients with RA and demonstrated that $\mathrm{T}$ cell responses to CII263-272 could be inhibited by the APLs with substitutions of the TCR contact residues. HA306-318 peptide can bind to HLA-DR4/1 molecules with a much higher affinity than CII263-272. ${ }^{7}$ Altered HA306-318 peptides with the substitutions of TCR contact residues are not recognised by HAspecific $\mathrm{T}$ cell clones, although these peptide analogues still bind to DR4/1. ${ }^{8}$ Therefore, altered HA peptides might be more efficient antagonist peptides in the inhibition of immune responses induced by HLA-DR4/1-specific peptides.

The mechanism by which APLs antagonise T cell responses cannot be based on HLA-DR blockade only. Alternatively, APLs may alter the cytokine production profile of T cells. ${ }^{9}{ }^{10}$ In this study we showed that APLs down regulated the production of IFN $\gamma$ compared with CII263-272, which 
promoted IFN $\gamma$ secretion. These results suggest that APLs are not Thl stimulators. It is not clear whether they regulate Th2 cells because no effects on IL4 production were found in the present study. Further studies are necessary to investigate whether APLs effectively inhibit $\mathrm{T}$ cell activation in vivo, such as in the HLA-DR4 transgenic animal model.

This work was supported by National Science Foundation of China (30271223) and National Outstanding Youth Grant of China (30025040).

\section{Authors' affiliations}

L Xia, L Ru, L Zhanguo, Department of Rheumatology and Immunology, People's Hospital, Peking University, 11 Xizhimen South St, Beijing 100044, China

Correspondence to: Dr L Zhanguo, lixia1969@163.com

Accepted 13 April 2005

\section{REFERENCES}

1 Weyand CM, Goronzy JJ. T cell response in rheumatoid arthritis: systemic abnormalities-local disease. Curr Opin Rheumatol 1999;11:210-17.
2 Gonzalez-Gay MA, Garcia-Porrua C, Hajeer AH. Influence of human leukocyte antigen-DRB1 on the susceptibility and severity of rheumatoid arthritis. Semin Arthritis Rheum 2002;31:355-60.

3 Sekine T, Kato T, Masuko-Hongo K, Nakamura H, Yoshino S, Nishioka K, et al. Type II collagen is a target antigen of clonally expanded $\mathrm{T}$ cell in the synovium of patients with rheumatoid arthritis. Ann Rheum Dis 1999:58:446-50

4 Diab BY, Lambert NC, L'Faqihi FE, Loubet-Lescoulie P, de Preval C, Coppin H. Human collagen II peptide 256-271 preferentially binds to HLA-DR molecules associated with susceptibility to rheumatoid arthritis. Immunogenetics 1999;49:36-44.

5 Qiang Z, Yongiing C, Houshan L, Weihong Z, Zhanguo L. Inhibition of T cell activation with HLA-DR1/DR4 restricted non-T-cell stimulation peptides. Hum Immunol 2003;64:857-65.

6 Yongjing C, Qiang Z, Zhanguo L. The inhibitory effect of altered collagen II peptide on HLA-DRB 1-restricted T-cell activation. Scand J Immunol 2005;61:260-5.

7 Rosloniec EF, Whittington KB, Zaller DM, Kang AH. HLA-DR1 (DRB1*0101) and DR4 (DRB1*0401) use the same anchor residues for binding an immunodominant peptide derived from human type II collagen. J Immunol 2002;168:253-9.

8 Rothbard JB, Busch R, Howland K, Bal V, Fenton C, Taylor WR, et al. Structural analysis of a peptide-HLA class II complex: identification of critical interactions for its formation and recognition by T cell receptor. Int Immunol 1989;1:479-86.

9 Singh RA, Zhang JZ. Differential activation of ERK, p38, and JNK required for Th1 and Th2 deviation in myelin-reactive T cells induced by altered peptide ligand. J Immunol 2004;173:7299-307.

10 Singh RA, Zang YC, Shrivastava A, Hong J, Wang GT, Li S, et al. Th1 and Th2 deviation of myelin-autoreactive T cells by altered peptide ligands is associated with reciprocal regulation of Lck, Fyn, and ZAP-70. J Immunol 1999; 163:6393-402.

\title{
Relationship between 5,10-methylenetetrahydrofolate reductase C677T gene polymorphism and methotrexate related toxicity in patients with autoimmune diseases receiving folic acid supplementation
}

\author{
M Speletas, N Papadopoulos, C Daiou, E Katodritou, A Pavlitou-Tsiontsi, V Galanopoulou
}

$\mathrm{T}$ he common polymorphism C677T of the 5,10-methylenetetrahydrofolate reductase (MTHFR) gene reduces enzyme activity and it has recently been associated with increased incidence of methotrexate (MTX) related toxicity in patients with cancer and rheumatoid arthritis. ${ }^{1-5}$ Considering that folate supplementation may reduce toxicity without affecting MTX efficiency, we conducted a retrospective study to analyse the effect of this polymorphism in patients with autoimmune diseases receiving folate supplementation.

Sixty three patients (F/M: 44/19, mean age 53.6 years, range 20-81) with autoimmune diseases who had been treated with MTX (7.5-15 mg/week, mean duration 35.8 months, range 2-121), were selected from the outpatient clinic between January and June 2004. Five of them had discontinued MTX treatment at the time of selection, because of adverse events or inefficiency. Thirty nine of the patients were receiving a combination of MTX with corticosteroids and/or other disease modifying antirheumatic drugs. All the patients were prescribed supplementary $2.5 \mathrm{mg}$ folic acid the day before and the day after MTX treatment. All participants were informed and consented to take part in the study. Table 1 shows the characteristics of the patients.

Genomic DNA was extracted from peripheral blood, and analysis of the MTHFR C677T polymorphism was performed
Table 1 Patients' characteristics

\begin{tabular}{|c|c|c|}
\hline \multirow[b]{2}{*}{ Characteristics } & \multicolumn{2}{|c|}{ Adverse effects } \\
\hline & $\begin{array}{l}\text { Present } \\
(\mathrm{n}=15)\end{array}$ & $\begin{array}{l}\text { Absent } \\
(n=48)\end{array}$ \\
\hline \multicolumn{3}{|l|}{ Age (years) } \\
\hline Mean (SD) & $56.8(10.8)$ & $52.6(16.6)$ \\
\hline Range & $33-72$ & $20-81$ \\
\hline $\operatorname{Sex}(F / M)$ & $11 / 4(2.75)$ & $33 / 15(2.2)$ \\
\hline \multicolumn{3}{|l|}{ Disease } \\
\hline Rheumatoid arthritis & 13 & 33 \\
\hline Psoriatic arthritis & 2 & 10 \\
\hline Ankylosing spondylitis & - & 3 \\
\hline Polymyositis & - & 2 \\
\hline \multicolumn{3}{|l|}{ Disease duration (months) } \\
\hline Mean (SD) & $36.6(30.1)$ & $35.6(29.6)$ \\
\hline Range & $2-121$ & $5-120$ \\
\hline \multicolumn{3}{|l|}{ Additional drugs (No (\%) of patients) } \\
\hline Corticosteroids (only) & $2(13)$ & $7(15)$ \\
\hline Other DMARDs ( \pm corticosteroids) & $8(53)$ & $22(46)$ \\
\hline \multicolumn{3}{|l|}{ MTHFR genotype, No (\%) } \\
\hline CC (wild type) & $10(67)$ & $13(27)$ \\
\hline $\mathrm{CT}$ (heterozygous) & $3(20)$ & $28(58)$ \\
\hline$\Pi$ (homozygous) & $2(13)$ & $7(15)$ \\
\hline
\end{tabular}

DMARDs, disease modifying antirheumatic drugs (included ciclosporin: 9 patients, hydroxychloroquine: 7 patients, and infliximab: 14 patients). 


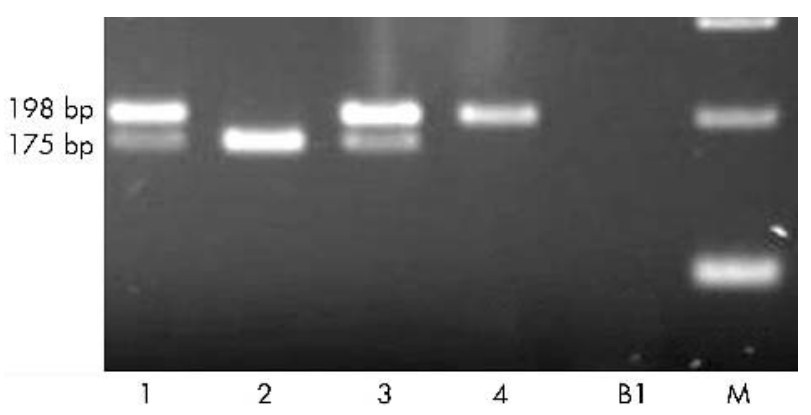

Figure 1 MTHFR C677T gene polymorphism established by PCRdigestion by Hinfl. The protocol of Frosst and coworkers was followed, with some modifications. The forward and reverse primers used were 5'-TGAAGGAGAAGGTGTCTGCGGGA-3' and

5'-AGGACGGTGCGGTGAGAGTG-3', respectively. The PCR conditions were 2 minutes at $94^{\circ} \mathrm{C}$ followed by 32 cycles $194^{\circ} \mathrm{C}$ for 30 seconds, $62^{\circ} \mathrm{C}$ for 30 seconds, $72^{\circ} \mathrm{C}$ for 60 seconds), and 5 minutes at $72^{\circ} \mathrm{C}$ after the last cycle. A $198 \mathrm{bp}$ fragment was amplified by PCR and subjected to Hinfl digestion (New England Biolabs, UK). The 677T allele contains an Hinfl site resulting in $175 \mathrm{bp}$ and 23 bp fragments, whereas a $C$ at position 677 (677C) does not. The PCR and digestion products were analysed in 3\% TBE agarose gels. Samples were categorised as homozygous for the thermolabile variant (677TT, lane 2), heterozygous for wild type and variant (C677T, lanes 1 and 3), or wild type (677CC, lane 4). Bl, negative control; M, 100 bp ladder molecular weight marker (Invitrogen, UK). The 23 bp fragments were not visible on agarose gels.

by polymerase chain reaction (PCR) amplification followed by restriction digestion analysis (fig 1). The statistical analysis was performed with SPSS statistical software.

The prevalence of the MTHFR C677T genotype in our cohort of patients was 37\% for 677CC (23/63 patients), 49\% for C677T (31/63 patients), and $14 \%$ for 677TT $(9 / 63$ patients). Fifteen (24\%) patients displayed one or more adverse effects (three nausea, eight neutropenia/pancytopenia, two a rise in transaminases, and three oral mucositis) and six of them discontinued MTX because of toxicity. Moreover, a further four patients discontinued MTX, one because of inefficiency, one because of emergence of secondary amyloidosis, and two because of emergence of neoplasia (total discontinuation 16\%). There was no significant difference in the MTX dosage, the demographic and clinical features between the patients with and without adverse effects during MTX treatment.

Interestingly, toxicity was more common in patients with normal genotype than in those with both heterozygotes and homozygotes $(p=0.005$ analysed by Fisher's exact test). Moreover, in multivariate analysis of variance the MTHFR genotype was the most important independent risk factor predisposing to MTX related toxicity $(\mathrm{p}=0.042)$, compared with the other variables analysed-namely, age, sex, duration, and type of treatment (MTX alone or in combination with corticosteroids and/or other disease modifying antirheumatic drugs).

To our knowledge, this is the first study illustrating an inverse relationship between an MTHFR C677T variant and MTX related toxicity, in which the presence of toxicity was more common in patients with the normal 677CC genotype. In previous studies the presence of an MTHFR C677T polymorphism was associated with a higher incidence of MTX related toxicity in patients with rheumatoid arthritis and cancer, and also with an increased risk of discontinuing MTX treatment because of adverse events. ${ }^{2-5}$ However, most patients in those studies did not receive folate supplementation, or they received it after the emergence of toxicity. Interestingly, other studies did not support such a correlation..$^{78}$ A possible explanation of our results, similar to the protective effect of the MTHFR C677T polymorphism in carcinogenesis, ${ }^{10}$ is that this polymorphism, in the presence of adequate folate supply, results in sustained ability of DNA synthesis and repair through increased synthesis of purines and thymidine, and subsequently in decreased MTX related toxicity.

In conclusion, our data suggest that a folate supply is critical among patients with autoimmune diseases and different MTHFR genotypes. When folic acid is given, subjects with MTHFR 677TT and C677T may be at reduced risk of MTX related toxicity, probably because of the sustained ability of DNA synthesis. This protective effect is absent in subjects with MTHFR 677CC and in subjects with MTHFR 677TT and C677T receiving MTX without folate supply, as has been shown in previous studies. In addition, our results indicate the importance of genotyping to provide useful information for individualised treatment in patients with autoimmune diseases.

\section{Authors' affiliations}

M Speletas, C Daiou, E Katodritou, A Pavlitou-Tsiontsi, Haematology and Immunology Department, Papageorgiou General Hospital, Thessaloniki, Greece

N Papadopoulos, V Galanopoulou, Rheumatology Unit, Papageorgiou General Hospital, Thessaloniki, Greece

Correspondence to: Dr M Speletas, Dimarchou K Tsirou 8, 54248

Thessaloniki, Greece; speletas@otenet.gr

Accepted 14 April 2005

\section{REFERENCES}

1 Borchers AT, Keen CL, Cheema GS, Gershwin ME. The use of methotrexate in rheumatoid arthritis. Semin Arthritis Rheum 2004;34:465-83.

2 Ulrich CM, Yasui Y, Storb R, Schubert MM, Wagner JL, Bigler J, et al. Pharmacogenetics of methotrexate: toxicity among marrow transplantation patients varies with the methylenetetrahydrofolate reductase C677T polymorphism. Blood 2001;98:231-4.

3 van Ede AE, Laan RFJM, Blom HJ, Huizinga TWJ, Haagsma GJ, Giesendorf BAJ, et al. The C677T mutation in the methylenetetrahydrofolate reductase gene. A genetic risk for methotrexate-related elevation of liver enzymes in rheumatoid arthritis patients. Arthritis Rheum 2001;44:2525-30.

4 Urano W, Taniguchi A, Yamanaka H, Tanaka E, Nakajima H, Matsuda Y, et al. Polymorphisms in the methylenetetrahydrofolate reductase gene were associated with both the efficacy and the toxicity of methotrexate used for the treatment of rheumatoid arthritis, as evidenced by single locus and haplotype analysis. Pharmacogenetics 2002;12:183-90.

5 Toffoli G, Russo A, Innocenti F, Corona G, Tumolo S, Sartor F, et al. Effect of methylenetetrahydrofolate reductase $677 \mathrm{C} \rightarrow$ T polymorphism on toxicity and homocysteine plasma level after chronic methotrexate treatment with ovarian cancer patients. Int J Cancer 2003; 103:244-9.

6 Frosst P, Blom HJ, Milos R, Goyette P, Sheppard CA, Matthews RG, et al. A candidate genetic risk factor for vascular disease: a common mutation in methylenetetrahydrofolate reductase. Nature Genet 1995;10:111-17.

7 Kumagai K, Hiyama K, Oyama T, Maeda H, Kohno N. Polymorphisms in the thymidine synthase and methylenetetrahydrofolate reductase genes and sensitivity to the low-dose methotrexate therapy in patients with rheumatoid arthritis. Intern J Mol Med 2003;1 1:593-600.

8 Berkun Y, Levartovsky D, Rubinow A, Orbach H, Aamar S, Grenader T, et al. Methotrexate related adverse effects in patients with rheumatoid arthritis are associated with the A1298C polymorphism of the MTHFR gene. Ann Rheum Dis 2004;63:1227-31.

9 Chen J, Giovannucci E, Kelsey K, Rimm EB, Stampfer MJ, Colditz GA, et al. A methylenetetrahydrofolate reductase polymorphism and the risk of colorectal cancer. Cancer Res 1996;56:4862-4.

10 Skibola CF, Smith MT, Kane E, Roman E, Rollinson S, Cartwright RA, et al. Polymorphisms in the methylenetetrahydrofolate reductase gene are associated with susceptibility to acute leukemia in adults. Proc Natl Acad Sci USA 1999;96:12810-15. 


\title{
Primary antiphospholipid syndrome: a unique presentation with multiple visceral aneurysms
}

\author{
V Koutoulidis, A Chatziioannou, C Kostopoulos, S Kontogiannis, V Skiadas, D Mourikis, L Vlahos
}

W present a unique case of a young woman with a proven primary type of antiphospholipid syndrome (APS) and multiple abdominal visceral aneurysms. Only one other case with such an association has been reported before to our knowledge. The presence of visceral aneurysms poses a therapeutic challenge because the anticoagulation treatment may be catastrophic in view of the risk of aneurysm rupture and abdominal bleeding.

A 38 year old woman was transferred from the department of obstetrics and gynaecology of the hospital, because of peripheral oedema. Two days earlier she had had a third trimester pregnancy loss. She had a history of four unexplained deaths of morphologically normal fetuses at the third trimester, during the past 10 years. She was the mother of a healthy 7 year old child. A diagnosis of primary APS was made based on clinical and serological criteria. Anticardiolipin IgG antibodies were present at a moderate level ( $48 \mathrm{GPL}$ units; normal <19 GPL). There was no evidence of a concurrent systemic disease as documented in all detailed laboratory examinations performed for almost 1 year. Computed tomography of the abdomen disclosed multiple partially thrombosed and calcified visceral aneurysms affecting the splenic, hepatic, and both renal arteries, which were further documented with selective angiography (fig 1). The course of the patient's disease was uneventful for 3 years, but progressive pulmonary, renal, and hepatic malfunction then started to develop. She progressively deteriorated and died from multiorgan failure. Postmortem examination confirmed the presence of the splachnic aneurysms without any evidence of rupture.

APS is one of the most important causes of hypercoagulability. ${ }^{1}$ About $50 \%$ of patients with APS do not have an associated systemic disease and are labelled as cases of primary APS. ${ }^{2}{ }^{3}$ The association of APS and arterial aneurysms is controversial and poses a critical therapeutic dilemma. Lifelong anticoagulation remains the fundamental treatment for APS and may obviously be hazardous in the presence of multiple aneurysms. Although in most cases of secondary APS the presence of arterial aneurysms can be attributed to the underlying systemic disease, ${ }^{45}$ the pathogenesis of such aneurysms in primary APS—such as in our case-remains unclear. ${ }^{6}$

Kong et al reported a case of a young man with systemic lupus erythematosus and secondary APS who presented with acute abdominal pain owing to a ruptured right hepatic artery aneurysm. ${ }^{4}$ He was also found to have aneurysms of the left hepatic artery and splenic artery on necropsy. The aetiology of these aneurysms according to the authors and based on histological examination of the aneurysmal wall, was found to be systemic lupus erythematosus vasculitis.

Dongola and Foord described a case of primary APS presenting with varied arterial abnormalities. ${ }^{6}$ These included the presence of a large number of micro- and macroaneurysms of hepatic, renal, and mesenteric arteries. There was insufficient evidence to merit a concurrent diagnosis of polyarteritis nodosa or other associated systemic condition. The authors suggested that the arterial abnormalities in this patient might have been inherent to the syndrome itself and that APS can present protean vascular abnormalities, which represent a wide spectrum without associated vasculitis.

Our case is a further example of the unusual presentation of APS without any association with other syndromes, as shown by all laboratory examinations and documented by postmortem histological examination of the diseased arteries. Based on a literature review, we did anticoagulate the patient because there was serious concern about thromboembolic disease, despite the presence of multiple intra-abdominal aneurysms. $^{78}$ We also followed all the other treatment protocols, including steroids and plasmapheresis, with the intention of provoking regression of the aneurysms. Such a regression was noted in a case of APS associated with polyarteritis nodosa, with a significant decrease in both the number and size of splachnic aneurysms after intensive treatment. ${ }^{5}$ In our case this treatment was unsuccessful because the postmortem examination showed the presence of the aneurysms, albeit without any evidence of aneurysm rupture or internal bleeding.

Despite the fact that the patient received all the appropriate supportive treatment, her disease progressed and she
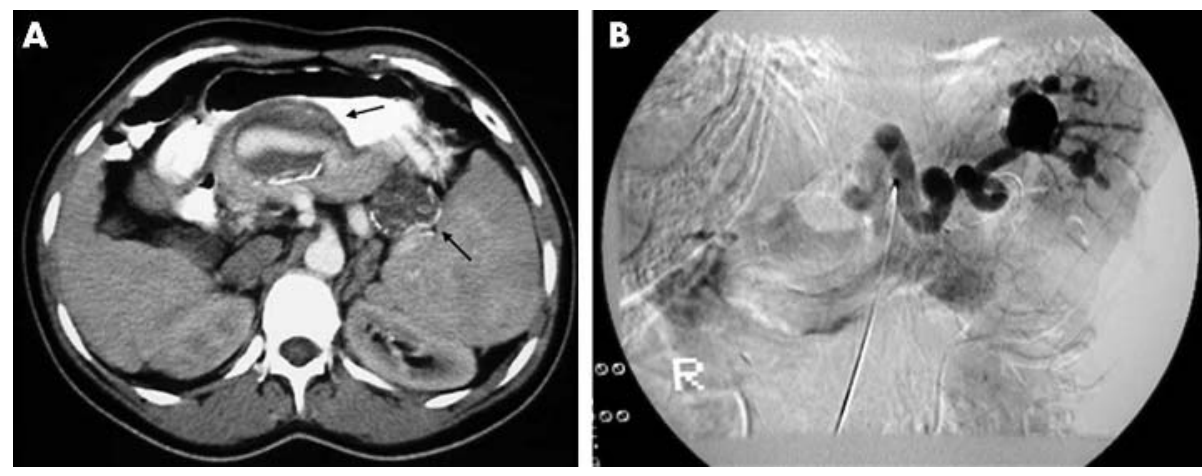

Figure 1 Contrast enhanced computed tomography of the abdomen (A) shows large, partially thrombosed aneurysms of the splenic and hepatic arteries (arrows). Multiple splenic artery aneurysms are confirmed on selective angiography (B). 
eventually died from multiorgan failure. Oral anticoagulation probably prevented the development of major arterial and venous thromboembolic disease, without causing the rupture of any of the pre-existing aneurysms. However, anticoagulation did not prevent the progression to multiorgan failure, which can be attributed to alterations in the microvascular circulation.

In conclusion, we think that multiple splachnic aneurysms probably represent part of the spectrum of vascular abnormalities of primary APS. If such aneurysms are identified, lifetime anticoagulation should still be considered as the preferred treatment in order to prevent deep venous thrombosis and/or pulmonary embolism, despite the risk of bleeding complications.

\section{Authors' affiliations}

V Koutoulidis, A Chatziioannou, C Kostopoulos, S Kontogiannis, V Skiadas, D Mourikis, L Vlahos, Areteion University Hospital, 76 Vas. Sophias Avenue, 11527 Athens, Greece
Correspondence to: Mr V Koutoulidis, vkout1968@yahoo.gr

Accepted 18 April 2005

\section{REFERENCES}

1 Harris EN. Syndrome of the black swan. Br J Rheumatol 1987;26:324-6.

2 Asherson RA, Khamashta MA, Ordi-Ros J, Derksen RH, Machin SJ, Barquinero J, et al. The primary antiphospholipid syndrome: major clinical and serological features. Medicine (Baltimore) 1989;68:366-74.

3 Vianna JL, Khamashta MA, Ordi-Ros J, Font J, Cervera R, Lopez-Soto A, et al. Comparison of the primary and secondary antiphospholipid syndrome: a European multicenter study of 114 patients. Am J Med 1994:96:3-9.

4 Kong KO, Koh ET, Lee HY, Wee KP, Feng PH. Abdominal crisis in a young man with systemic lupus erythematosus. Lupus 2002;11:186-9.

5 Dasgupta B, Almond MK, Tanqueray A. Polyarteritis nodosa and the antiphospholipid syndrome. Br J Rheumatol 1997;36:1210-12.

6 Dongola NA, Foord KD. Angiographic features associated with antiphospholipid syndrome. Br J Radiol 2000;73:1215-18.

7 Derksen RH, de Groot PG, Kater L, Nieuwenhuis HK. Patients with antiphospholipid antibodies and venous thrombosis should receive long term anticoagulant treatment. Ann Rheum Dis 1993:52:689-92.

8 Khamashta MA, Cuadrado MJ, Mujic F, Taub NA, Hunt BJ, Hughes GR. The management of thrombosis in the antiphospholipid-antibody syndrome. N Engl J Med 1995;332:993-7.

\section{A family with diffuse idiopathic skeletal hyperostosis}

\section{Gorman, A S M Jawad, I Chikanza}

W e report a family with diffuse idiopathic skeletal hyperostosis (DISH). The most striking occurrence was severe cervical disease without extensive dorsal involvement. From the tissue typing results of our two sibling patients, it appears less likely that, if there is a hereditary component, it is linked to HLA status. It remains to be seen whether this is a new disease entity or an unusual familial variant of DISH. We are unaware of a similar published report.

A 23 year old man was referred with a painful stiff neck of 3 years' duration. On examination, all movements of his cervical spine were restricted. Other spinal movements were normal. Inflammatory markers were normal and HLA-B27 was negative. An $x$ ray examination of the sacroiliac joints, thoracic and lumbar spine were unremarkable. However, the cervical spine radiograph showed gross anterior osteophytosis (fig 1A).

This man's 24 year old sister had been seen 7 years previously. She described a 6 year history of worsening neck pain and stiffness. On examination, movements of the cervical spine were severely limited in all directions, with mild limitation of the thoracic spine. An $x$ ray examination and inflammatory markers were normal and HLA-B27 was negative. Five years later, the clinical findings had scarcely changed. However, although the sacroiliac joints were still normal, there was now marked osteophytosis around the hip joints with gross osteophytosis and ankylosis of the cervical spine (fig 1B). Two years later, this advanced cervical pathology precipitated cervical myelopathy.

The father of these patients was first seen at 52 years of age despite having a "30 year history of ankylosing spondylitis". He had a strong family history of the disease, with brother, sister, and mother affected. On examination, all spinal movements were markedly reduced. Movements of both hips were severely restricted and bilateral elbow fixed flexion deformities were present. Inflammatory markers were normal and HLA-B27 was negative. An $x$ ray examination showed normal sacroiliac joints, advanced osteophytosis and degeneration of the hip joints, and ankylosis of the cervical spine (fig lC). His hip disease required prompt replacement surgery.

All these patients had radiological changes suggestive of DISH. Two of this patient's siblings also had the disease, as do his other two offspring (they are receiving care at different hospitals). The first two patients described here were tissue typed: these siblings only shared alleles at DRB3 and the C locus, which occur frequently in the general population.

DISH is an ossifying, non-inflammatory, non-erosive enthesopathy favouring the dorsal spine but sparing the sacroiliac joints. By contrast, ankylosing spondylitis is an inflammatory condition with enthesopathies facing joints, always affecting the sacroiliac joints. DISH affects $3-6 \%$ of the population over 40 years of age and $11 \%$ aged over 70 years. ${ }^{1}$ It is twice as common in men and occurs more frequently in certain racial groups: it is common in Japanese and Pima Indians but rare in black and Asian races. ${ }^{1}$ Other causes of hyperostosis or bony excrescences include spondylitis deformans, ankylosing spondylitis, trauma, fluorosis, treatment with retinoids, ochronosis, acromegaly, hypoparathyroidism, and x-linked hypophosphataemic osteomalacia, but there was nothing in the history, physical examination, or the investigations to suggest that our three patients had any of those conditions. ${ }^{2}$

In the cervical spine, ossification of the posterior longitudinal ligament (OPLL) is commonly seen. This phenomenon is often called "Japanese disease" owing to its predominance in the Japanese population. ${ }^{3}$ OPLL displays a strong genetic component with high concordance in twins and families. ${ }^{4} 5$ Various modes of inheritance have been suggested, including HLA linkage. ${ }^{6}$ In DISH, however, although there are racial differences, no strong familial tendency has been demonstrated. Neither is there a proven 

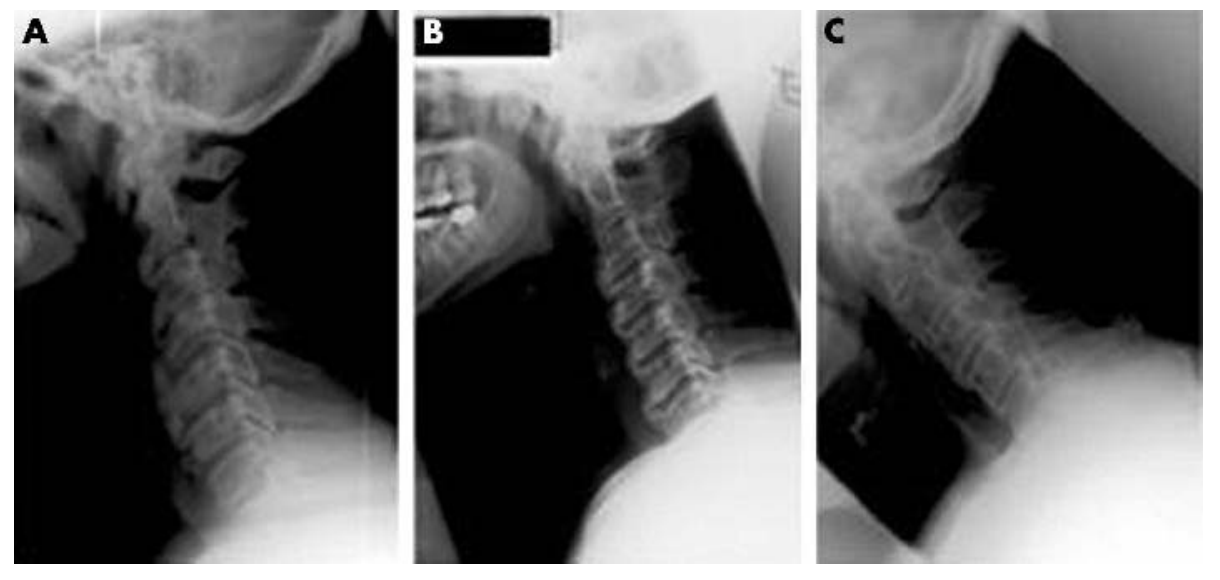

Figure 1 Lateral $x$ ray findings of the cervical spine of the son $(A)$, the daughter $(B)$, and the father $(C)$, showing severe anterior osteophytosis.

HLA link, as found between HLA-B27 and the spondyloarthropathies.

Although our patients were diagnosed as DISH, there are some atypical features. The most striking of these is severe cervical disease without extensive dorsal involvement. Forestier and Rotes-Querol in their classification criteria, considered involvement of at least three intervertebral bodies in the dorsal spine to be essential. ${ }^{7}$ However, Utsinger's criteria do not include this as a necessary feature. ${ }^{8}$ One similar case has been described: a 71 year old patient presented with similar cervical findings and sparing of the dorsal spine and sacroiliac joints. Difficulty was found classifying the condition as either DISH or ankylosing spondylitis. ${ }^{9}$ Another unusual feature in our cases is the strong familial pattern. From the tissue typing results of our two sibling patients, it appears less likely that, if there is a hereditary component, it is linked to HLA status.

It thus remains to be seen whether this is a new disease entity or an unusual familial variant of DISH.

\section{Authors' affiliations}

C Gorman, A S M Jawad, I Chikanza, Rheumatology Department, Newham University Hospital, Glen Road, London E13 8SL, UK
Correspondence to: Dr A S M Jawad, The Royal London Hospital, Bancroft Road, London E1 4DG, UK; alismjawad1@hotmail.com

Accepted 3 May 2005

\section{REFERENCES}

1 Mazieres B, Rovensky J. Non-inflammatory enthesopathies of the spine: a diagnostic approach. Bailliere's Clinical Rheumatol 2000;14:201-17.

2 Utsinger PD. Diffuse idiopathic skeletal hyperostosis. Clin Rheum Dis 1985; 11:325-51.

3 Ono K, Yonenobu K, Miyamoto S, Okada K. Pathology of ossification of the posterior longitudinal ligament and ligament flavum. Clin Orthop Relat Res 1999;359:18-26.

4 Koga H, Sakou T, Taketomi E, Hayashi K, Numasawa T, Harata S, et al. Genetic mapping of ossification of the posterior longitudinal ligament of the spine. Am J Genet 1998;62:1460-7.

5 Hamanishi C, Tan A, Yamane T, Tomihara M, Fukuda K, Tanaka S. Ossification of the posterior longitudinal ligament. Autosomal trait. Spine 1995;20:205-7.

6 Matsunga S, Yamaguchi M, Hayashi K, Sakou T. Genetic analysis of ossification of the posterior longitudinal ligament. Spine 1999;21:937-8.

7 Forestier J, Rotes-Querol J. Senile ankylosing hyperostosis of the spine. Ann Rheum Dis 1950;9:321-30.

8 Utsinger PD. Diffuse skeletal hyperostosis (DISH, ankylosing hyperostosis). In: Moskowitz RW, Howell DS, Goldberg VM, Mankin HJ, eds. Osteoarthritis. Diagnosis and management. Philadelphia: Saunders, 1984:225-33.

9 Helfenstein M. Severe cervical ankylosis - DISH, AS or what? Br J Rheumatol 1989;28:299-303.

\title{
Antiphospholipid antibodies in patients with scleroderma: prevalence and clinical significance
}

\author{
G Sanna, M L Bertolaccini, A Mameli, G R V Hughes, M A Khamashta, A Mathieu
}

A ntiphospholipid antibodies (aPL) are detected in a variety of autoimmune disorders, most commonly systemic lupus erythematosus, but also in some infectious diseases, lymphoproliferative disorders, and even in apparently healthy people.

Although a wide prevalence of aPL in systemic sclerosis has been reported (between 0 and $41 \%$ ), most studies have focused on anticardiolipin antibodies (aCL) and very little is known about other aPL in this disease. We determined the prevalence and clinical significance of aCL, antibodies to $\beta_{2}$-glycoprotein I (anti- $\beta_{2}$ GPI), and antibodies to phosphatidylserine-prothrombin complex (aPS-PT) in 25 patients with scleroderma ( 18 with limited and 7 with diffuse scleroderma, as defined by LeRoy et $\mathrm{al}^{1}$ ) (table 1). Twenty four patients were female (median age 50 years (range 28-70), median disease duration 3 years (range 1-20)). One patient had a history of venous thrombosis. Of the 17 patients who had ever been pregnant, five had an adverse obstetric history. Two patients had miscarriages (before the 10th week of gestation), two patients had a fetal death (at the 10th week of 
Table 1 Clinical characteristics of patients with scleroderma*

\begin{tabular}{lclc}
\hline Characteristics & $\begin{array}{c}\text { Limited } \\
(\mathbf{n}=\mathbf{1 8})\end{array}$ & $\begin{array}{l}\text { Diffuse } \\
(\mathbf{n}=\mathbf{7})\end{array}$ & $\begin{array}{l}\text { All } \\
(\mathbf{n = 2 5})\end{array}$ \\
\hline Calcinosis & 2 & 1 & 3 \\
Raynaud's phenomenon & 17 & 6 & 23 \\
Oesophageal dysmotility & 9 & 4 & 13 \\
Sclerodactyly & 17 & 5 & 22 \\
Telangiectasia & 6 & 2 & 8 \\
Pulmonary manifestations & 11 & 5 & 16 \\
$\quad$ Interstitial lung disease & 10 & 5 & 15 \\
$\quad 3$ Pulmonary hypertension & 3 & 0 & 3 \\
Cardiac manifestations & 1 & 0 & 1 \\
Renal manifestations & 0 & 0 & 0 \\
Bowel disease & 0 & 0 & 0 \\
\hline
\end{tabular}

*All patients were attending the $2^{\text {nd }}$ Chair of Rheumatology, Rheumatology Division and Centre for Systemic Rheumatic Diseases, Cagliari University Hospital, Cagliari, Italy.

gestation or later), and one patient had a premature birth (before the 34th week of gestation) due to severe preeclampsia. Platelet count was normal in all patients. Only one patient had a prolonged activated partial thromboplastin time. One hundred healthy donors with no relevant medical history comprised the control group.

aCL, anti- $\beta_{2}$ GPI, and aPS-PT were detected by enzyme linked immunosorbent assay (ELISA). ${ }^{2-4}$

aPL were present in $8 / 25$ patients. Table 2 shows the distribution of aPL in patients and controls. aCL for IgG/IgM and aCL IgG were more frequently found in patients with scleroderma than in controls $(24 \% v 5 \%$, odds ratio $=6(1.7-$ $21.7), \mathrm{p}=0.008$ and $16 \% \vee 3 \%$, odds ratio $=6.1(1.2-2.9)$, $\mathrm{p}=0.03$, respectively). The prevalence of anti- $\beta_{2}$ GPI did not differ between patients and controls ( $8 \% v 3 \%$ for IgG/IgM, $4 \% \vee 2 \%$ for IgG, and $4 \% v 1 \%$ for IgM).

Interestingly, patients with telangiectasia and pulmonary hypertension had IgM aPS-PT more frequently than those without $(37.5 \% v 0 \%$, relative risk $=4.4(2.0-9.5), \mathrm{p}=0.02$ and $66.6 \% \vee 4.5 \%$, relative risk $=14.6(1.8-116.9), \mathrm{p}=0.03$, respectively). No associations were found between the other aPL analysed and clinical manifestations of scleroderma.

One patient with scleroderma who had had venous thrombosis also had IgG aCL at low titres. Of the two patients with a history of miscarriages $(<10$ th week of gestation), one had IgG anti- $\beta_{2}$ GPI and the other IgM aPSPT. None of the patients who had fetal death $(n=2)$ or prematurity $(\mathrm{n}=1)$ had aPL.

Although the presence of all aPL was more common in patients with scleroderma than in healthy controls $(32 \% \mathrm{v}$ $5 \%)$, the clinical manifestations of antiphospholipid syndrome were not frequently seen in these patients.

The prevalence of aCL in scleroderma has been reported to range from $0 \%{ }^{5}$ to $41 \% .^{6}$ In this study, only one patient had a history of venous thrombosis and aCL at low titres, suggesting that this manifestation may have been aCL related.

Parodi et al described anti- $\beta_{2}$ GPI in $3 / 90(3.3 \%)$ patients with scleroderma, ${ }^{7}$ whereas Schoenroth et al reported a prevalence of $8 \%$ when studying 26 patients with this disease. ${ }^{8}$ These studies are in agreement with our findings.

Although the prevalence of aPS-PT was low in our study, these antibodies were more frequently found in patients with
Table 2 Distribution of aPL in patients with scleroderma and controls

\begin{tabular}{|c|c|c|c|c|}
\hline & $\begin{array}{l}\text { Scleroderma } \\
(n=25)\end{array}$ & $\begin{array}{l}\text { Limited } \\
\text { ( } n=18)\end{array}$ & $\begin{array}{l}\text { Diffuse } \\
(n=7)\end{array}$ & $\begin{array}{l}\text { Controls } \\
(n=100)\end{array}$ \\
\hline Any aPL & 8 & 6 & 2 & 5 \\
\hline $\mathrm{aCL}$ & 6 & 5 & 1 & 5 \\
\hline $\lg G$ & 4 & 3 & 1 & 3 \\
\hline $\lg M$ & 2 & 2 & 0 & 2 \\
\hline Anti- $\beta_{2}$ GPI & 2 & 2 & 0 & 3 \\
\hline $\lg G$ & 1 & 1 & 0 & 2 \\
\hline $\lg M$ & 1 & 1 & 0 & 1 \\
\hline aPS-PT & 3 & 2 & 1 & 0 \\
\hline $\lg G$ & 0 & 0 & 0 & 0 \\
\hline $\lg M$ & 3 & 2 & 1 & 0 \\
\hline
\end{tabular}

telangiectasia and pulmonary hypertension, supporting the data from Hasegawa et al in their cohort of 112 patients with scleroderma. ${ }^{9}$ Overall, these findings suggest that aPS-PT may be a marker of vascular involvement in patients with scleroderma. However, as this is a very small study, further research is warranted to confirm or reject this hypothesis.

In summary, aPL are commonly found in patients with scleroderma but the "typical" clinical manifestations of antiphospholipid syndrome are not frequently seen in these patients.

\section{Authors' affiliations}

G Sanna, M L Bertolaccini, G R V Hughes, M A Khamashta, Lupus Research Unit, The Rayne Institute, King's College London School of Medicine, St Thomas' Hospital, London, UK

G Sanna, A Mameli, A Mathieu, Cattedra di Reumatologia II, Università di Cagliari, Cagliari, Italy

G Sanna, Department of Rheumatology, Homerton University NHS

Foundation Trust, London, UK

Correspondence to: DrM A Khamashta, munther.khamashta@kcl.ac.uk

Accepted 16 April 2005

\section{REFERENCES}

1 LeRoy EC, Black C, Fleischmajer R, Jablonska S, Krieg T, Medsger TA Jr, et al. Scleroderma (systemic sclerosis): classification, subsets and pathogenesis. J Rheumatol 1988;15:202-5.

2 Harris EN, Pierangeli S, Birch D. Anticardiolipin wet workshop report. Fifth International Symposium on antiphospholipid antibodies. Am J Clin Pathol 1994;101:616-24.

3 Amengual O, Atsumi T, Khamashta MA, Koike T, Hughes GRV. Specificity of ELISA for antibody to beta 2-glycoprotein I in patients with antiphospholipid syndrome. Br J Rheumatol 1996;35:1239-43

4 Bertolaccini ML, Atsumi T, Koike T, Hughes GR, Khamashta MA. Antiprothrombin antibodies detected in two different assay systems. Prevalence and clinical significance in systemic lupus erythematosus. Thromb Haemost 2005;93:289-97

5 Fonollosa V, Selva A, Lima J, Simeon CP, Vilardell M. Anticardiolipin antibodies in systemic sclerosis. J Am Acad Dermatol 1991;25:133-4.

6 Passaleva A, Massai G, Matucci-Cerinic M, Domeneghetti MP, Sharifian J, Lotti $T$, et al. Immunological abnormalities in a group of patients with limited cutaneous systemic sclerosis and prominent vascular disease. Autoimmunity 1990;6:283-91.

7 Parodi A, Drosera M, Barbieri L, Rebora A. Antiphospholipid antibody system in systemic sclerosis. Rheumatology (Oxford) 2001;40:111-12.

8 Schoenroth L, Fritzler M, Lonzetti L, Senecal JL. Antibodies to beta2 glycoprotein I and cardiolipin in SSc. Ann Rheum Dis 2002;61:183-4.

9 Hasegawa M, Sato S, Yanaba K, Komura K, Yamazaki M, Takehara K. Autoantibodies against phosphatidylserine-prothrombin complex in patients with systemic sclerosis. Ann Rheum Dis 2004;63:1514-17. 


\title{
Remitting seronegative symmetrical synovitis with pitting oedema/polymyalgia rheumatica after infection with Mycoplasma pneumoniae
}

\author{
M Matsuda, Y Shimojima, T Gono, W Ishii, K Kaneko, M Yazaki, S-i Ikeda
}

Ann Rheum Dis 2005;64:1797-1798. doi: 10.1136/ard.2005.037390

$\mathrm{R}$ emitting seronegative symmetrical synovitis with pitting oedema (RS3PE) is similar to polymyalgia rheumatica (PMR) in that it shows arthralgia attributable to tenosynovitis and muscle pain, occurring most commonly in the elderly, and shows a good response to corticosteroid treatment. ${ }^{1-4}$ The aetiologies of RS3PE and PMR are still unknown, but they are sometimes associated with neoplastic, other rheumatic, or infectious diseases. ${ }^{5} 6$

Here, we report clinical findings in four patients with RS3PE or PMR, or both, after infection with Mycoplasma pneumoniae. Increases in inflammatory reactions were seen in all patients, and the final diagnoses were RS3PE alone in patients 1 and 4, RS3PE associated with PMR in patient 2, and PMR alone in patient 3 (table 1 )..$^{7}$ None of the patients had a headache or blurred vision suggestive of associated temporal arteritis. Recent infection with $M$ pneumoniae was confirmed in all patients by the presence of IgM antibody to this agent in the serum and the results of serial serological studies with or without a positive cold agglutination test. Serum IgM levels were within the normal limits in all patients, and none showed positive results for serological tests for other infectious agents or autoantibodies such as rheumatoid factor or antinuclear antibody. All patients were treated successfully with oral prednisolone, but two relapsed during the tapering of this drug.

There are three possible characteristics of RS3PE/PMR after infection with $M$ pneumoniae. The first is the presence of common cold-like symptoms preceding RS3PE/PMR. Two of the four patients showed common cold-like symptoms, and antibiotics were given to patient No 1 because chest radiography demonstrated bilateral pleural effusion due to active infection with $M$ pneumoniae. The extremely high $\mathrm{C}$ reactive protein level with an almost normal erythrocyte sedimentation rate in patient 1 may have reflected previous infection with this agent.

The second characteristic is the frequent occurrence of relapse. RS3PE usually shows a good response to corticosteroid treatment, and is generally unlikely to relapse during tapering of drug treatment. ${ }^{1-4}$ However, relapse occurred soon after the start of tapering of oral prednisolone in two patients (Nos 1 (fig 1) and 2) in the present study.
The third characteristic is a broad spectrum of clinical phenotype. Patients 1, 2, and 4 had oedema in the hands and feet, which is typical of RS3PE, while patient 3 had muscle pain alone, suggestive of PMR. Patient 2 was diagnosed as having RS3PE associated with PMR at the onset of disease, but at relapse the patient had PMR symptoms alone. A possible explanation for these findings is that RS3PE and PMR may be classifiable as the same disease entity with their symptoms of multiple tenosynovitis, and many transitional forms have clinical features of both disorders. ${ }^{12}$ The clinical phenotypes manifested after infection with $M$ pneumoniae may be dependent on the host-disease relationship.

Several lines of evidence suggest that Mycoplasma species can cause rheumatic disorders. Previous exposure to Mycoplasma species is commonly confirmed by immunoblotting in patients with rheumatoid arthritis or juvenile rheumatoid arthritis, but polymerase chain reaction showed no detectable DNA of these agents in the synovial fluid or tissue. ${ }^{9}$ A prospective epidemiological study in Denmark indicated that the incidence of PMR varied in parallel with epidemics of $M$ pneumoniae infection. ${ }^{10}$ These findings indirectly suggest that Mycoplasma species may be related to the development of rheumatic disorders, and the present cases represent important direct evidence of the involvement of $M$ pneumoniae in the aetiology of RS3PE/PMR. Further studies in larger numbers of patients are necessary to clarify the pathogenetic mechanism of RS3PE/PMR after infection with this agent.

\section{Authors' affiliations}

M Matsuda, Y Shimojima, T Gono, W Ishii, K Kaneko, M Yazaki, S-i lkeda, Third Department of Medicine, Shinshu University School of Medicine, Matsumoto, Japan

Correspondence to: $\operatorname{Dr} M$ Matsuda, Third Department of Medicine, Shinshu University School of Medicine, 3-1-1 Asahi, Matsumoto 3908621, Japan; matsuda@hsp.md.shinshu-u.ac.jp

Accepted 23 April 2005

Table 1 Patient characteristics

\begin{tabular}{|c|c|c|c|c|c|c|c|c|c|c|c|}
\hline \multirow[b]{2}{*}{$\begin{array}{l}\text { Patient } \\
\text { No }\end{array}$} & \multirow[b]{2}{*}{$\begin{array}{l}\text { Onset } \\
\text { age/sex }\end{array}$} & \multirow[b]{2}{*}{$\begin{array}{l}\text { Diagnoses } \\
\text { at onset }\end{array}$} & \multirow{2}{*}{$\begin{array}{l}\text { Preceding } \\
\text { common } \\
\text { cold-like } \\
\text { symptoms }\end{array}$} & \multicolumn{4}{|c|}{ Laboratory tests at onset } & \multirow[b]{2}{*}{$\begin{array}{l}\text { Abnormal } \\
\text { findings on } \\
\text { chest } x \text { ray }\end{array}$} & \multicolumn{2}{|c|}{ Treatment at onset } & \multirow[b]{2}{*}{$\begin{array}{l}\text { Diagnoses } \\
\text { at relapse }\end{array}$} \\
\hline & & & & $\begin{array}{l}\text { ESR* }^{*} \\
(\mathrm{~mm} / \\
\text { lst h) }\end{array}$ & $\begin{array}{l}\text { CRP* } \\
(\mathrm{mg} / \mathrm{l})\end{array}$ & $\begin{array}{l}\text { lg } M \text { antibody } \\
\text { to } M \\
\text { pneumoniae }\end{array}$ & $\begin{array}{l}\text { Cold } \\
\text { agglutination } \\
\text { test }\end{array}$ & & $\begin{array}{l}\text { Prednisolone } \\
\text { (mg/day) }\end{array}$ & Antibiotics & \\
\hline 1 & $82 / F$ & RS3PE & + & 24 & 111 & + & - & + & 20 & + & RS3PE \\
\hline 2 & $77 / F$ & $\begin{array}{l}\text { RS3PE and } \\
\text { PMR }\end{array}$ & + & 23 & 25 & + & - & - & 20 & - & PMR \\
\hline 3 & $75 / M$ & PMR & - & 25 & 33 & + & - & - & 20 & - & - \\
\hline 4 & $72 / F$ & RS3PE & - & 30 & 13 & + & + & - & 20 & - & - \\
\hline
\end{tabular}

*Normal values: ESR 3-11 mm/1 st h; CRP $<1 \mathrm{mg} / \mathrm{l}$.

CRP, C reactive protein; ESR, erythrocyte sedimentation rate; PMR, polymyalgia rheumatica; $R S 3 P E$, remitting seronegative symmetrical synovitis with pitting oedema. 

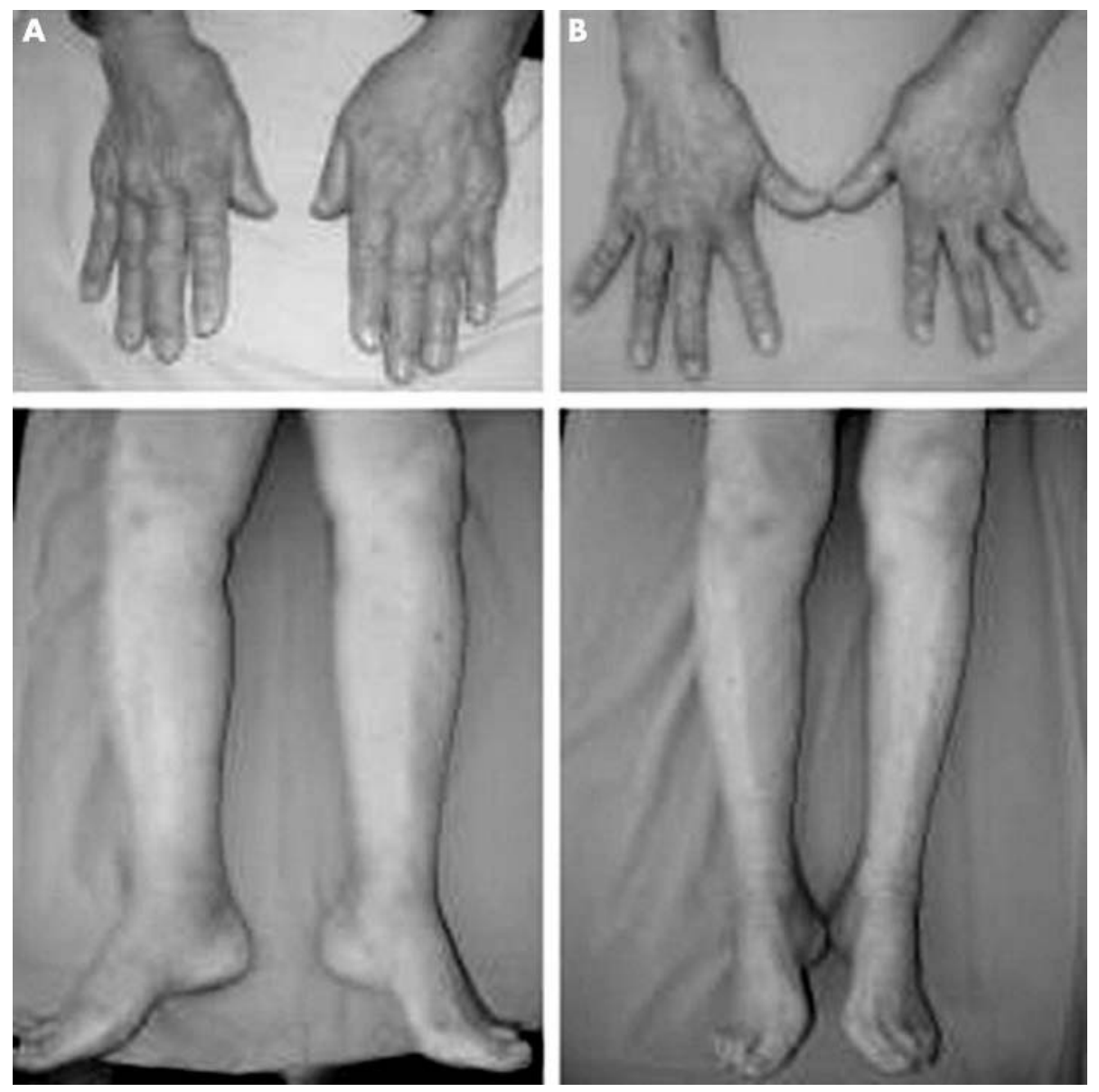

Figure 1 Patient 1 has oedema in both hands and feet, particularly in the latter (A), but this symptom quickly improved after starting oral prednisolone (B).

\section{REFERENCES}

1 Cantini F, Salvarani C, Olivieri I, Barozzi L, Macchioni L, Niccoli L, et al. Remitting seronegative symmetrical synovitis with pitting oedema (RS3PE) syndrome: a prospective follow up and magnetic resonance imaging study. Ann Rheum Dis 1999;58:230-6.

2 Cimmino MA, Silvestri E, Garlaschi G. Remitting seronegative symmetrical synovitis with pitting oedema (RS3PE) as recurrence of aborted PMR. Ann Rheum Dis 2001;60:303.

3 Queiro R. RS3PE syndrome: a clinical and immunogenetical study. Rheumatol Int 2004; $24: 103-5$.

4 Oide T, Ohara S, Oguchi K, Maruyama M, Yazawa M, Inoue K, et al. Remitting seronegative symmetrical synovitis with pitting edema (RS3PE) syndrome in Nagano, Japan: clinical, radiological, and cyłokine studies of 13 patients. Clin Exp Rheumatol 2004;22:91-8.

5 Torres A, Cuende E, De Pablos M, Lezaun M, Michaus L, Vesga JC. Remitting seronegative symmetrical synovitis with pitting edema associated with subcutaneous Streptobacillus moniliformis abscess. J Rheumatol 2001;28:1696-8.
6 Espinosa G, Font J, Munoz-Rodriguez FJ, Cervera R, Ingelmo M. Myelodysplastic and myeloproliferative syndromes associated with giant cell arteritis and polymyalgia rheumatica: a coincidental coexistence or a causal relationship? Clin Rheumatol 2002;21:309-13

7 McCarty DJ, O'Duffy JD, Pearson L, Hunter JB. Remitting seronegative symmetrical synovitis with pitting edema. RS3PE syndrome. JAMA 1985;254:2763-7

8 Cimmino MA, Salvarani C. Classification and assessment of rheumatic diseases: polymyalgia rheumatica and giant cell arteritis. Baillieres Clin Rheumatol 1995:9:515-27.

9 Hoffman RW, O'Sullivan FX, Schafermeyer KR, Moore TL, Roussell D, Watson-McKown $R$, et al. Mycoplasma infection and rheumatoid arthritis: analysis of their relationship using immunoblotting and an ultrasensitive polymerase chain reaction detection method. Arthritis Rheum 1997:40:1219-28.

10 Elling P, Plsson AT, Elling H. Synchronous variations of the incidence of temporal arteritis and polymyalgia rheumatica in different regions of Denmark: association with epidemics of Mycoplasma pneumoniae infection. J Rheumatol 1996;23:112-19.

\section{Peripheral neuropathy in patients with systemic rheumatic diseases treated with leflunomide}

\section{Metzler, A C Arlt, W L Gross, J Brandt}

eflunomide (LEF) was introduced as a new disease modifying antirheumatic drug in 1998. Up to -now hepatotoxicity, hypertension, and diarrhoea have been reported as adverse events. Peripheral neuropathy
(PNP) has been described in eight patients with rheumatoid arthritis (RA) and psoriatic arthritis. ${ }^{1-3}$ In the postmarketing surveillance PNP does not appear as a side effect. $^{4}$ 


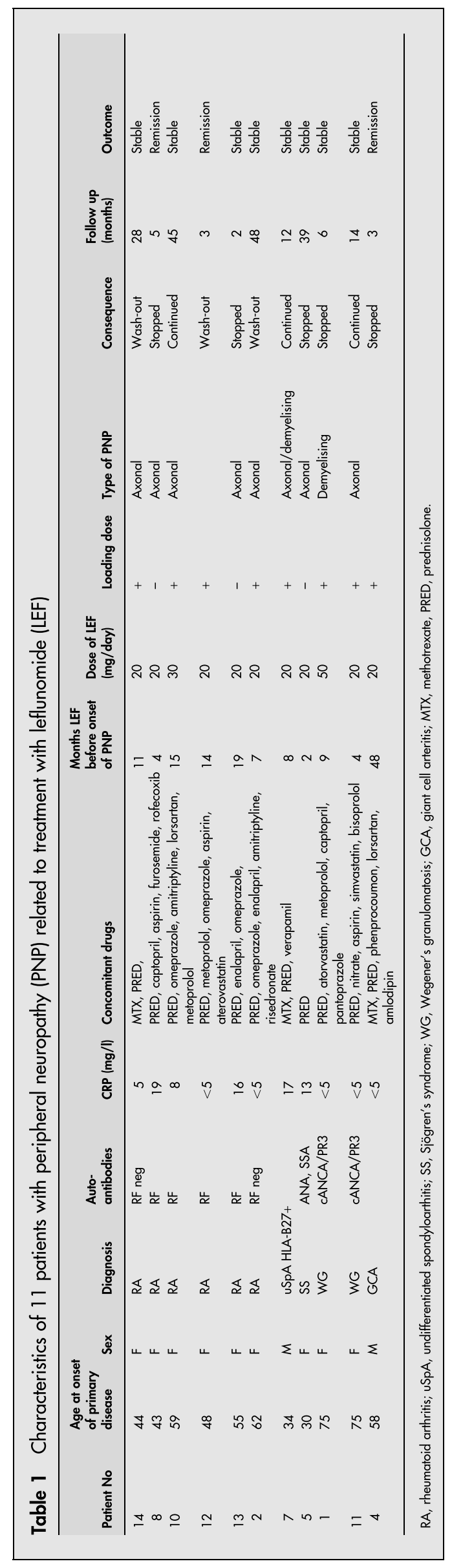

This first retrospective study aimed at evaluating whether LEF might be associated with PNP in a large cohort of patients with inflammatory rheumatic diseases.

All inpatients of a primary rheumatology clinic with systemic rheumatic diseases and treatment with LEF between August 1998 and May 2004 were retrospectively screened for a new onset of PNP. Patients with definite reasons for $\mathrm{PNP}$-for example, active vasculitis or collagenosis, diabetes mellitus, lack of vitamins, alcohol abuse, and neoplasms, were excluded. PNP was screened clinically and confirmed by electrophysiological examination.

Seven hundred and eighty five patients with LEF treatment were identified. PNP was diagnosed in $106(13.5 \%)$ patients. Ninety five patients were excluded with diabetes $(22$ patients), malignoma with cytotoxic treatment ( 2 patients), vasculitis (67 patients), and connective tissue diseases (4 patients). None of the patients with PNP and systemic rheumatic diseases potentially associated with PNP had any history of neuropathy or any clinical or serological signs of disease activity at the time of the first manifestation of PNP and were, for example, in remission.

Eleven of 785 ( $1.4 \%)$ patients were identified as having PNP that was possibly related to LEF (table 1). These 11 patients received LEF in a dose of 20-50 mg/day by mouth daily for RA in six patients, Wegener's granulomatosis in two, and for other inflammatory rheumatic diseases in three patients, respectively. PNP had occurred within a median of 9 months (range 2-48) after the start of LEF. Electroneurography and electromyography showed that PNP related to LEF had an acrodistal symmetric pattern in all patients. There was evidence of a mostly axonal affection in seven patients and demyelising changes in two. Patients with PNP induced by LEF were followed up for a median of 12 months (range 2-45). In eight patients LEF was stopped and, in addition, washed out in three of them. PNP improved in 3/8 (37.5\%) patients when LEF was stopped and remained stable in eight, independently of stopping or continuing treatment with LEF.

This retrospective analysis supports an association between treatment with LEF and the occurrence of PNP. Comparable data about the epidemiology of PNP are rare; in 1992 Walters et al described a prevalence of $2.9 \%$ in a cohort of 480 healthy controls. ${ }^{5}$ Whether there is a dose dependent neurotoxic effect of LEF is unclear. One patient of our cohort established a PNP after an accidental intake of a higher dose LEF ( $50 \mathrm{mg} /$ day). In contrast with this experience, no increase of PNP was seen in two different studies in which 20 patients with Wegener's granulomatosis were treated with 30-40 mg/day LEF for 2 years $^{6}$ and in a preliminary report of 11 patients with RA who received LEF in a dosage of $40 \mathrm{mg}$ for a mean period of 4.4 months. $^{7}$

The underlying pathogenetic mechanism is still unknown. When LEF was first used for the treatment of RA the possibility that LEF might induce vasculitis was discussed after a report of a new onset of secondary vasculitis in two patients with RA. ${ }^{8}$ In the meantime further safe and effective treatment of primary systemic vasculitides did not support this hypothesis. ${ }^{6}$ Thus one might argue that LEF was not effective enough to suppress a secondary vasculitis in these two cases. Interestingly, in three patients with RA and LEF related PNP nerve biopsies were performed showing a predominant axonopathic process and vasculitis of the arterioles.

In conclusion, PNP is a new adverse event of LEF. Therefore we recommend close neurological monitoring during treatment with LEF. In suspect cases stopping and washing out of LEF by cholestyramine should be considered.

Authors' affiliations

C Metzler, W L Gross, J Brandt, Department of Rheumatology, University of Schleswig-Holstein, Campus Luebeck and Rheumaklinik Bad Bramstedt, Germany 
A C Arlt, Department of Neurology, Rheumaklinik Bad Bramstedt, Germany

Correspondence to: $\operatorname{Dr} C$ Metzler, University Hospital of SchleswigHolstein, Campus Luebeck, Department of Rheumatology, Ratzeburger Allee 160, D-23538 Luebeck, Germany; metzler@rheuma-zentrum.de

Accepted 14 May 2005

\section{REFERENCES}

1 Carulli MT, Davies UM. Peripheral neuropathy: an unwanted effect of leflunomide? Rheumatology (Oxford) 2002;41:952-3.
2 Hill CL. Leflunomide-induced peripheral neuropathy: rapid resolution with cholestyramine wash-out. Rheumatology (Oxford) 2004;43:809.

3 Bharadwai A, Haroon N. Peripheral neuropathy in patients on leflunomide. Rheumatology (Oxford) 2004;43:934.

4 van Riel PL, Smolen JS, Emery P, Kalden JR, Dougados M, Strand CV, et al. Leflunomide: a manageable safety profile. J Rheumatol Suppl 2004;71:21-4.

5 Walters DP, Gatling W, Mullee MA, Hill RD. The prevalence of diabetic distal sensory neuropathy in an English community. Diabet Med 1992;9:349-53.

6 Metzler C, Fink C, Lamprecht P, Gross WL, Reinhold-Keller E. Mainenance of remission with leflunomide in Wegener's granulomatosis. Rheumatology (Oxford), 2004:43:315-20.

7 Fiehn C, Rochel E, Ho AD, Max R. Dose escalation of leflunomide (LEF) to $40 \mathrm{mg}$ once daily in patients with rheumatoid arthritis and insufficient response to standard dose LEF. Ann Rheum Dis 2004;63:746-77.

8 Bruyn GAW, Griep EN, Korff KJ. Leflunomide for active rheumatoid arthritis. Lancet 1999;353:1883-4.

\section{Vasculitis, antiphospholipid antibodies, and renal artery stenosis}

\section{S N Paul, S R Sangle, A N Bennett, M El-Hachmi, R Hangartner, G R Hughes, D P D'Cruz}

A ntiphospholipid antibodies (aPL) are considered to be non-pathogenic in patients with vasculitis. We present five patients with primary vasculitis who had aPL and renal artery stenosis (RAS); one of these patients had coexistent renal pathology due to primary vasculitis, and micro- and macropathology due to renal manifestations of the antiphospholipid syndrome.

A 44 year old white smoker presented with sinusitis, haemoptysis, and arthritis. She was normotensive. A chest $x$ ray demonstrated cavitating lesions. She was cANCA positive and fulfilled the American College of Rheumatology criteria for Wegener's granulomatosis (WG). ${ }^{1}$ aPL were detected, although she lacked a history of thromboses or pregnancy morbidity. Her serum $\mathrm{C}$ reactive protein level was raised at $100 \mathrm{mg} / \mathrm{l}$. Clinical and serological remission was achieved with intravenous cyclophosphamide followed by maintenance methotrexate and corticosteroid treatment.

After discontinuing corticosteroids, she became hypertensive and her previously normal renal function deteriorated. Her serum creatinine rose to $154 \mu \mathrm{mol} / \mathrm{l}$ and she developed mild proteinuria $(0.41 \mathrm{~g} / 24$ hours $)$. Her cANCA titre rose to 40 with a rise in erythrocyte sedimentation rate to $28 \mathrm{~mm} / \mathrm{lst}$ h. She remained aPL positive. Repeat echocardiography demonstrated mild mitral and tricuspid regurgitation, moderate aortic regurgitation with normal left ventricular function. Renal biopsy demonstrated crescentic focal and segmental proliferative glomerulonephritis with features of a thrombotic microangiopathy (figs $\mathrm{lA}$ and B). She received further intravenous cyclophosphamide and corticosteroid, with symptomatic resolution and improvement in serum creatinine $(122 \mu \mathrm{mol} / \mathrm{l})$, but the mild proteinuria persisted.

At follow up, she had persistent hypertension (220/100 mm $\mathrm{Hg}$ ) despite treatment with three antihypertensive drugs, including an angiotensin converting enzyme inhibitor, proteinuria, and rising serum creatinine; oral cyclophosphamide was started. Her proteinuria increased to $2.14 \mathrm{~g} / 24$ hours and her serum creatinine rose to over $200 \mu \mathrm{mol} / \mathrm{l}$ within a few weeks. Magnetic resonance angiography of her renal arteries demonstrated tight ostial stenosis of the right renal artery with poststenotic dilatation ( fig lC) and a non-atheromatous aorta. After angioplasty (fig lD) the patient's renal function improved, with a serum creatinine of $76 \mu \mathrm{mol} / \mathrm{l}$ and 24 hour urinary protein of $1.45 \mathrm{~g} / 24$ hours. She was formally anticoagulated with warfarin.
Table 1 includes four other patients with primary vasculitis, aPL, persistent hypertension, and RAS.

Renal disease is not uncommon in WG, Churg-Strauss, and microscopic polyangiitis. ${ }^{2}$ Untreated it may lead to end stage renal failure. Hypertension seen in vasculitis may be secondary to corticosteroid treatment or renal disease.

Atherosclerosis is the major cause of RAS $(>90 \%)$, with a minority of cases due to fibromuscular dysplasia. ${ }^{3}$ Hypertension is a recognised feature of antiphospholipid syndrome. Recently, a high prevalence of RAS $(26 \%)$ was demonstrated in relatively young hypertensive patients with antiphospholipid syndrome. ${ }^{4}$ In our cohort, all the stenotic lesions were well defined and distal to the ostia, and the aortae showed no evidence of atherosclerosis.

We believe that RAS seen in our cohort may be associated with aPL. The relatively young age of our patients and the absence of atheromatous aortae on magnetic resonance angiography argues against the atherosclerotic type of RAS seen in elderly patients. A possible mechanism for the development RAS in our cohort is thrombosis, accelerated atherosclerosis, and/or smooth muscle hypertrophy. ${ }^{4}$

Earlier reports have suggested that the presence of aPL in primary vasculitis is not pathogenic. ${ }^{5}{ }^{6}$ There are no reports to date of vasculitis associated with RAS and aPL. However, there have been case reports of aneurysmal dilatation of the renal arteries and RAS in polyarteritis nodosa and Takayasu's arteritis; none of our cohort had either of these diseases.

In summary, the presence of systemic vasculitis and aPL may not be as benign as previously thought. When faced with patients with primary vasculitis, aPL, and uncontrolled hypertension, the possibility of RAS should be considered.

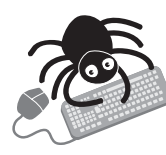

A colour version of fig 1 can be seen at http:// www.annrheumdis.com/supplemental

\section{Authors' affiliations}

S N Paul, S R Sangle, A N Bennett, M El-Hachmi, G R Hughes, D P D'Cruz, Louise Coote Lupus Unit, St Thomas' Hospital, London SE 1 7EH, UK

R Hangartner, Department of Histopathology, St Thomas' Hospital, London SEI 7EH, UK 

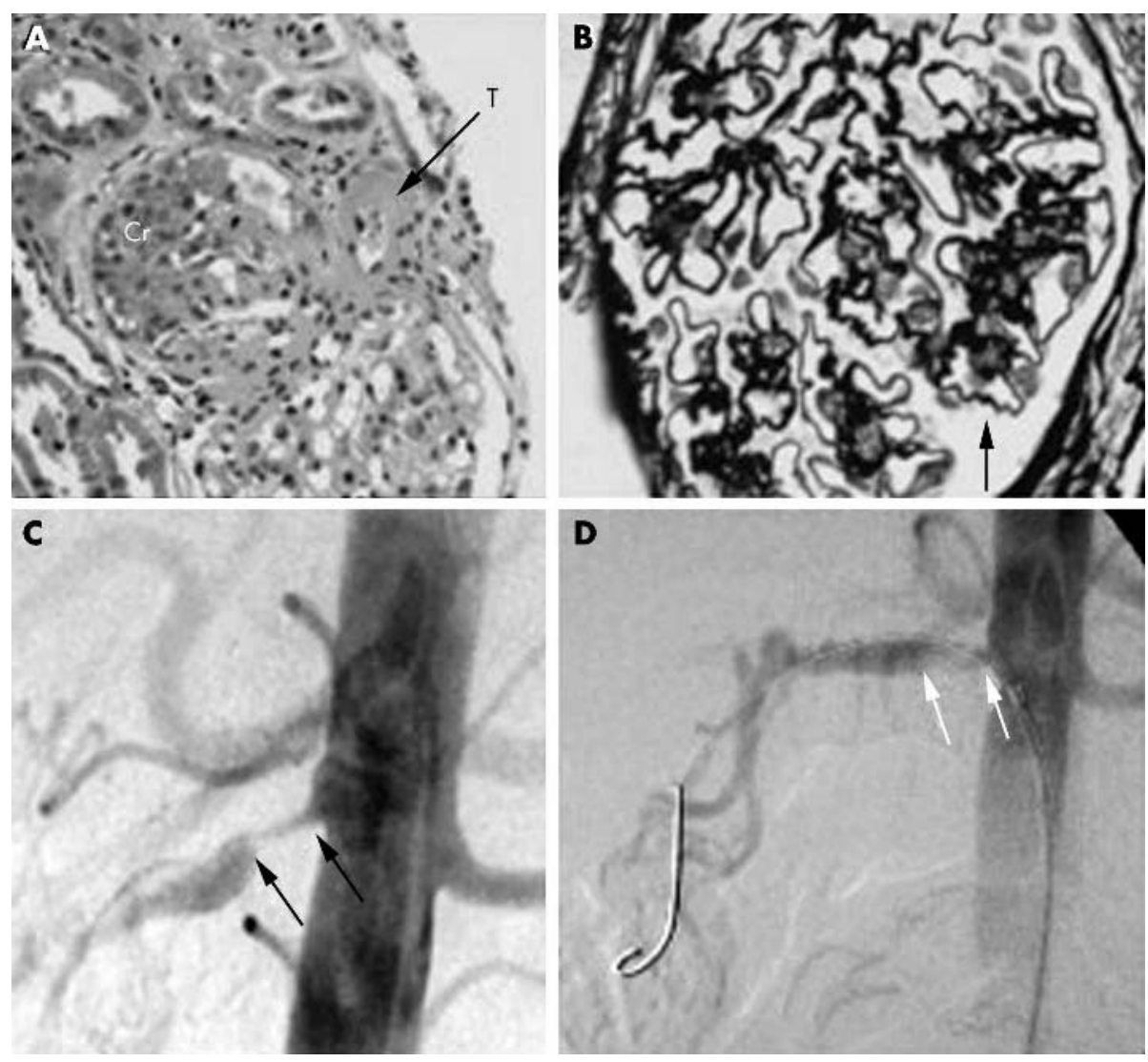

Figure 1 (A) Haematoxylin and eosin renal biopsy stain demonstrating a large cellular crescent ( $\mathrm{Cr}$ ) and intraluminal thrombus. (B) Periodic acidSchiff/methanamine silver stain of renal biopsy specimen. The glomerular capillary walls and mesangial matrix are black. The folding/crenation (single arrow) suggests ischaemic contraction. (C) Renal angiogram demonstrating right renal artery ostial stenosis with post-stenotic dilatation (black arrows). Note the smooth non-atheromatous appearance of the aorta. (D) Percutaneous transluminal angioplasty of right renal artery stenosis (white arrows). A colour version of the figure can be seen at http://www.annrheumdis.com/supplemental.

Table 1 Patients with primary vasculitis, aPL, persistent hypertension, and RAS

\begin{tabular}{|c|c|c|c|c|}
\hline Patient No, sex & $\begin{array}{l}\text { Type of vasculitis, organ involvement, } \\
\text { and treatment }\end{array}$ & ANCA & $\begin{array}{l}\text { Renal artery stenosis } \\
\text { history }\end{array}$ & aPL and thrombosis history \\
\hline 1 , female* & $\begin{array}{l}\text { WG diagnosed age } 44 \\
\text { Respiratory, joint, renal } \\
\text { Cyclophosphamide, corticosteroids }\end{array}$ & cANCA & $\begin{array}{l}\text { R RAS diagnosed } 4 \text { years } \\
\text { after vasculitis }\end{array}$ & $\begin{array}{l}\text { Positive lupus anticoagulant on more } \\
\text { than two occasions } \\
\text { Cardiac valve lesions, renal thrombotic } \\
\text { microangiopathy }\end{array}$ \\
\hline 2 , male & $\begin{array}{l}\text { Churg-Strauss diagnosed age } 46 \\
\text { Cerebral vasculitis, cardiomyopathy, asthma, } \\
\text { sinusitis, necrotising glomerulonephritis } \\
\text { Corticosteroids, azathioprine, methotrexate, } \\
\text { cyclophosphamide }\end{array}$ & pANCA & $\begin{array}{l}\text { L RAS diagnosed } 18 \text { years } \\
\text { after vasculitis }\end{array}$ & $\begin{array}{l}\text { Positive lupus anticoagulant on two } \\
\text { occasions } \\
1 \text { Cerebrovascular accident } \\
1 \text { Deep vein thrombosis }\end{array}$ \\
\hline 3 , female & $\begin{array}{l}\text { WG diagnosed age } 47 \\
\text { Pulmonary haemorrhage, crescentic } \\
\text { glomerulonephritis, peripheral neuropathy } \\
\text { Azathioprine, cyclophosphamide, co-trimoxazole }\end{array}$ & cANCA & $\begin{array}{l}\text { Bilateral RAS and coeliac } \\
\text { artery stenosis diagnosed } \\
7 \text { years after onset of } \\
\text { vasculitis }\end{array}$ & $\begin{array}{l}\text { Positive lupus anticoagulant and } \\
\text { anticardiolipin antibodies on two } \\
\text { occasions } \\
\text { Miscarriages, superficial } \\
\text { thrombophlebitis }\end{array}$ \\
\hline 4, male & $\begin{array}{l}\text { WG diagnosed age } 56 \\
\text { Pulmonary haemorrhage, epistaxis, and scleritis } \\
\text { Methotrexate, cyclophosphamide, prednisolone, } \\
\text { co-trimoxazole }\end{array}$ & cANCA & $\begin{array}{l}\text { L RAS, superior mesenteric } \\
\text { artery stenosis diagnosed } \\
4 \text { years after onset of } \\
\text { vasculitis }\end{array}$ & $\begin{array}{l}\text { Lupus anticoagulant positive on two } \\
\text { occasions } \\
\text { No thromboses }\end{array}$ \\
\hline 5 , female & $\begin{array}{l}\text { Primary idiopathic systemic vasculitis diagnosed } \\
\text { age } 42 \\
\text { Inflammatory arthropathy, coronary arteritis } \\
\text { Azathioprine, methotrexate, prednisolone }\end{array}$ & Not present & $\begin{array}{l}\text { Bilateral RAS diagnosed } \\
15 \text { years after onset of } \\
\text { vasculitis }\end{array}$ & $\begin{array}{l}\text { Positive lupus anticoagulant on two } \\
\text { occasions }\end{array}$ \\
\hline
\end{tabular}


The authors have no competing interests.

Correspondence to: Dr D P D'Cruz, david.d'cruz@kcl.ac.uk

Accepted 5 May 2005

\section{REFERENCES}

1 Leavitt RY, Fauci AS, Bloch DA, Michel BA, Hunder GG, Arend WP, et al. The American College of Rheumatology criteria for the classification of Wegener's granulomatosis. Arthritis Rheum 1990;33:1101-7.
2 Aasarod K, Iversen BM, Hammerstrom J, Bostad L, Vatten L, Jorstad S. Wegener's granulomatosis: clinical course in 108 patients with renal Wegener's granulomatosis: clinical course in 108 patients
involvement. Nephrol Dial Transplant 2000;15:61 1-18.

3 Safian RD, Textor SC. Renal artery stenosis. N Engl J Med 2001;344:431-42.

4 Sangle SR, D'Cruz DP, Jan W, Karim MY, Khamashta MA, Abbs IC, et al. Renal artery stenosis in the antiphospholipid (Hughes) syndrome and hypertension. Ann Rheum Dis 2003;62:999-1002.

5 Lamprecht P, deGroot K, Schnabel A, Csernok E, Liedvogel B, Gross WL. Anticardiolipin antibodies and antibodies to $\beta_{2}$-glycoprotein I in patients with Wegener's granulomatosis. Rheumatology (Oxford) 2000;39:568-70.

6 Hansen KE, Moore KD, Ortel TL, Allen NB. Antiphospholipid antibodies in patients with Wegener's granulomatosis and polyarteritis nodosa. Arthritis Rheum 1999;42:2250-2.

\title{
Therapeutic interleukin (IL) 1 blockade normalises increased ILI $\beta$ and decreased tumour necrosis factor $\alpha$ and ILI0 production in blood mononuclear cells of a patient with CINCA syndrome
}

\author{
M Seitz, R K Kamgang, H U Simon, P M Villiger
}

Ann Rheum Dis 2005;64:1802-1803. doi: 10.1136/ard.2005.036749

M utations in the cold-induced autoinflammatory syndrome l (CIAS1) gene cause inherited chronic autoinflammatory disorders such as Muckle-Wells/ familial cold urticaria and chronic infantile neurological cutaneous and articular (CINCA) syndrome. ${ }^{12}$ Up regulation of interleukin (IL) $1 \beta$ was recently reported in unstimulated monocytes obtained from a patient with CINCA syndrome, ${ }^{3}$ and active inflammatory disease resolved rapidly and completely during treatment with anakinra in patients with CINCA $^{4}$ and with Muckle-Wells syndrome. ${ }^{56}$

We report on a 47 year old male patient with the CIAS I mutation T348M presenting classical clinical features of CINCA syndrome. The disease was refractory to conventional antiinflammatory drugs and infliximab, but was successfully treated with daily subcutaneous injections of $100 \mathrm{mg}$ of recombinant human ILl receptor antagonist (anakinra, Kineret; Amgen, Cambridge, UK). Before and after therapeutic ILl blockade, we assessed clinical and humoral inflammatory disease activity and cytokine release (IL1 $\beta$, tumour necrosis factor $\alpha(\mathrm{TNF} \alpha)$, IL6, and IL10 in cell culture supernatants; R\&D enzyme linked immunosorbent assay (ELISA) kits with lower detection limits of 3.9, 15.6, 3.13, and $7.8 \mathrm{pg} / \mathrm{ml}$ ) from Ficoll-isolated and either unstimulated or lipopolysaccharide (LPS; $100 \mathrm{ng} / \mathrm{ml}$ ) stimulated peripheral blood mononuclear cells (PBMC; $1 \times 10^{6} / \mathrm{ml}$ RPMI $1640+5 \%$ fetal calf serum) after 48 hours of cell culture.

Cell-specific staining for monocytes was performed with mouse FITC-antihuman CD14 (eBioscience; San Diego, CA). Flow cytometry data were acquired only with propidium iodide negative cells on a FACSCalibur equipped with four lasers, and data were analysed using CellQuest software (BD Biosciences).

Concomitant symptomatic drug treatment was kept unchanged. Before anakinra treatment the patient showed typical clinical and serological signs of active inflammatory disease, including rash, polyarthritis of wrists and metacarpal joints, leucocytosis with neutrophilia, and a moderate acute phase response. After 2 days the rash completely vanished and synovitis and morning stiffness had markedly improved. After 3 weeks complete clinical remission with absence of cutaneous and articular symptoms was achieved. Raised $C$ reactive protein levels and erythrocyte sedimentation rate normalised and leucocyte and platelet counts decreased, whereas monocyte numbers did not change and lymphocyte counts increased (table 1).

At the functional level we did observe an enormous ILl $\beta$ release from monocytes after LPS stimulation before treatment. This dramatically and progressively declined upon treatment with anakinra. Surprisingly, the secretion of IL6 from activated PBMC was completely blocked, and similar to our previous finding in the same patient, ${ }^{7}$ we observed a completely deficient IL10 and in this case a deficient TNF $\alpha$ response of monocytes to LPS stimulation before treatment. Therapeutic ILl blockade, however, restored both, spontaneous as well as LPS-induced TNF $\alpha$ and IL10 secretion.

Based on the pretreatment findings on stimulation of PBMC in this patient, and in addition to our previous

Table 1 Laboratory measures in a patient with CINCA syndrome before and during treatment with recombinant human ILI receptor antagonist

\begin{tabular}{llll}
\hline Measure & Baseline & 3 Weeks & 9 Weeks \\
\hline C reactive protein (mg/l) & 47 & 9 & 4 \\
Erythrocyte sedimentation rate & 40 & 3 & 8 \\
(mm/1 st h) & & & \\
Haemoglobin (g/l) & 10.9 & 12.5 & 11.6 \\
Leucocyte count (109//) & 15.6 & 8.1 & 9.4 \\
Monocyte count (109//) & 0.47 & 0.50 & 0.47 \\
Lymphocyte count (109/I) & 1.4 & 2.87 & 2.87 \\
Platelet count (109//) & 528 & 403 & 419 \\
CD14+ cells among PBMC (\%) & 1.28 & 1.35 & 1.15 \\
& & & \\
Cytokine secretion by PBMC (pg/m/) & $<3.9$ & $<3.9$ & $<3.9$ \\
Spontaneous IL1 $\beta$ & 8534 & 2943 & 271 \\
LPS-induced IL1 $\beta$ & $<3.13$ & $<3.13$ & $<3.13$ \\
Spontaneous IL6 & 1921 & $<3.13$ & $<3.13$ \\
LPS-induced IL6 & $<15.6$ & 225 & 188 \\
Spontaneous TNF $\alpha$ & $<15.6$ & 732 & 220 \\
LPS-induced TNF $\alpha$ & $<7.8$ & 162 & 170 \\
Spontaneous IL10 & $<7.8$ & 163 & 175 \\
LPS-induced IL10 & & & \\
\hline & & & \\
\hline
\end{tabular}


finding, ${ }^{7}$ we suggest that there is a defect of LPS responsiveness of monocytes to the induction of TNF $\alpha$ and ILlO.

This case confirms the excellent response of CINCA syndrome to treatment with human ILl receptor antagonist. Our results suggest that patients with this hereditary autoinflammatory disorder may exhibit a profound dysregulation of ILl and TNF $\alpha$ synthesis. However, we cannot exclude the possibility that the inability to detect TNF $\alpha$ before application of ILl receptor antagonist owed more to a rapid decay of TNF $\alpha$ rather than reduced production. As this dysregulation is reversed by treatment with ILl receptor antagonist, one may argue that therapeutic inhibition of otherwise aberrant ILl $\beta$ secretion results in a compensatory up regulation or less decay of TNF $\alpha$ to maintain the host's capacity to react to microbial agents and other types of danger signals. Furthermore, the overall up regulation of the TNF $\alpha$ pathway by interaction at the ILl pathway illustrates that the cytokine imbalance is not due to a defect, but rather to a dysregulation. Finally, our results provide an explanation for the reason why TNF blocking agents are ineffective in certain autoinflammatory diseases.

\section{Authors' affiliations}

M Seitz, R K Kamgang, P M Villiger, Department of Rheumatology and Clinical Immunology/Allergology, University Hospital, Bern, Switzerland H U Simon, Department of Pharmacology, University of Bern, Bern, Switzerland
Correspondence to: Professor M Seitz, michael.seitz@insel.ch

Accepted 3 May 2005

\section{REFERENCES}

1 Hoffmann HM, Mueller JL, Broide DH, Wanderer AA, Kolodner RD. Mutations of a new gene encoding a putative pyrin-like protein causes familial cold autoinflammatory syndrome and Muckle-Wells syndrome. Nat Genet $2001 ; 29: 301-5$.

2 Neven B, Callebaut I, Pieur AM, Feldmann G, Bodemer C, Lepore L, et al. Molecular basis of the spectral expression of CIASI mutations associated with phygocytic cell-mediated autoinflammatory disorders CINCA/NOMID, MWS, and FCU. Blood 2004; 103:2809-15

3 Aksentijevich I, Nowak M, Mallah M, Chae JJ, Watford WT, Hofmann SR, et al. De novo CIAS1 mutations, cytokine activation, and evidence of genetic heterogeneity in patients with neonatal-onset multisystem inflammatory disease (NOMID): a new member of the expanding family of pyrin-associated autoinflammatory diseases. Arthritis Rheum 2002;46:3340-8.

4 Granel B, Serratrice J, Disdier P, Weiller PJ. Dramatic improvement with anakinra in a case of chronic infantile neurological cutaneous and articular (CINCA) syndrome. Rheumatology 2005;44:689-90.

5 Hawkins PN, Lachmann HJ, McDermott MF. Interleukin-1-receptor antagonist in the Muckle-Wells syndrome. N Engl J Med 2003;348:2583-4.

6 Hawkins PN, Lachmann HJ, Aganna E, McDermott MF. Spectrum of clinical features in Muckle-Wells syndrome and response to anakinra. Arthritis Rheum 2004:50:607-12.

7 Bihl T, Vassina E, Boettger MK, Goldbach-Mansky R, Seitz M, Villiger PM, et al. The T348M mutated form of cryopyrin is associated with defective LPSinduced IL-10 production in CINCA syndrome. Ann Rheum Dis 2005;64:1380-1.

\section{Reversible posterior leucoencephalopathy in scleroderma}

\section{W L Poon, C C Mok}

Ann Rheum Dis 2005;64:1803-1804. doi: 10.1136/ard.2005.038273

A 34 year old Chinese woman with limited scleroderma presented with rapid onset of mental confusion and generalised tonic-clonic seizures. Her blood pressure control had been unsatisfactory in the preceding 4 weeks despite the use of three anti-hypertensive agents, which included an angiotensin converting enzyme inhibitor. Malignant hypertension (blood pressure 240/140 mm $\mathrm{Hg}$ on admission) was evident, with typical fundoscopic abnormalities, microangiopathic haemolytic anaemia, and rapidly deteriorating renal function with acute oligouric renal failure (increase in serum creatinine from baseline of 86 to $495 \mu \mathrm{mol} / \mathrm{l}$ in 3 days). There was, however, no evidence of left ventricular failure.

Treatment was given in the intensive care unit with infusions of labetalol (up to $150 \mathrm{mg} / \mathrm{h}$ ) and iloprost (up to $10 \mu \mathrm{g} / \mathrm{h}$ ), large doses of captopril (150 mg/day), and haemodialysis. An urgent magnetic resonance imaging (MRI) scan
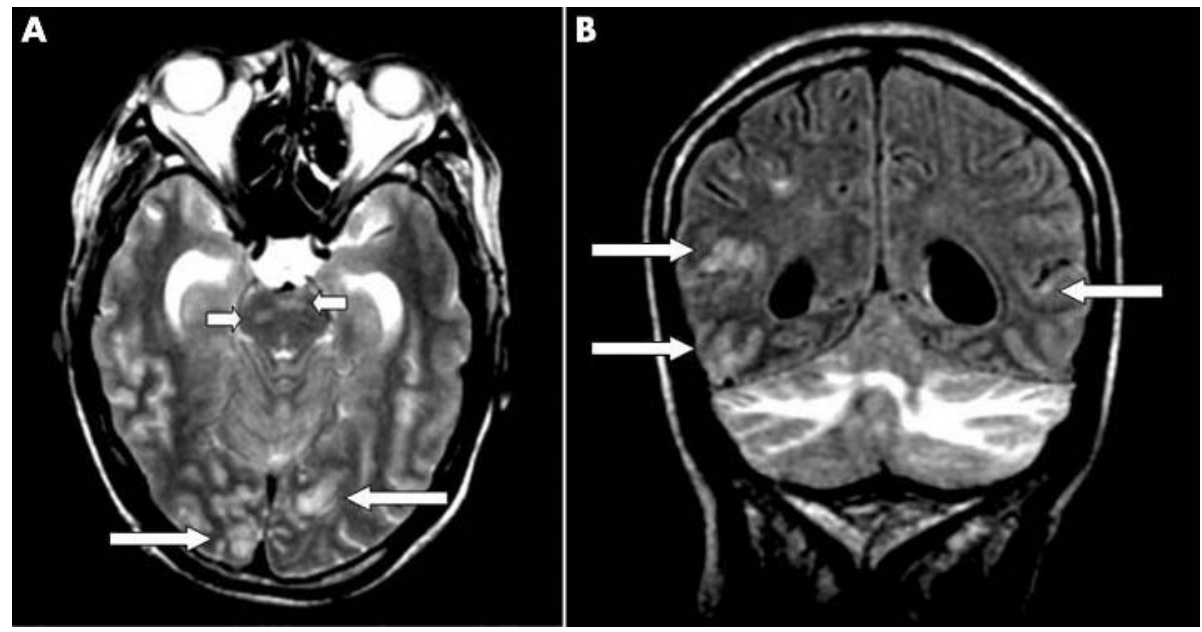

Figure 1 (A) Axial $T_{2}$ weighted and (B) coronal fluid attenuated inversion recovery (FLAIR) images showing bilateral abnormal hyperintensities in the white matter of the cerebellum, cortex, and subcortical white matter of the occipital lobes (long arrows), and in the brain stem (short arrows). 
of the brain showed marked vasogenic oedema distributed symmetrically at the cortex, and subcortical white matter of the occipital lobes, the cerebellum, and the brain stem (fig 1). With control of hypertension and dialysis support, she gradually regained full consciousness without neurological deficits. A repeat MRI scan 2 weeks later demonstrated complete resolution of the lesions. The clinical picture was compatible with a reversible posterior leucoencephalopathy syndrome (RPLS).

RPLS is a clinical syndrome characterised by headache, seizures, visual disturbances, and confusion. The MRI finding is often characteristic, with abnormal $\mathrm{T}_{2}$ weighted hyperintensity affecting primarily the white matter of the territories of the posterior circulation. ${ }^{1}$ The cerebral cortex and the anterior circulation territories may also be affected, but usually to a lesser extent. RPLS has been described in an increasing number of medical conditions, including hypertensive encephalopathy, eclampsia, neurotoxicity related to calcineurin inhibitors, and uraemic encephalopathy. Reversible vasogenic oedema is the underlying pathology of the abnormal MRI signal intensities. The exact pathogenesis of RPLS remains elusive but a break down of the autoregulation of cerebral blood flow and endothelial dysfunction resulting in leakage of fluid into the interstitium has been postulated.
RPLS has been described in many rheumatic diseases, including systemic lupus erythematosus, systemic vasculitides, and the overlap syndromes. ${ }^{2}{ }^{3}$ However, we believe that this is the first report of RPLS in adult patients with limited scleroderma. Prompt recognition and treatment of this condition is essential as it is potentially reversible.

\section{Authors' affiliations \\ W L Poon, Department of Diagnostic Radiology, Tuen Mun Hospital, Hong Kong \\ C C Mok, Department of Medicine, Tuen Mun Hospital, Hong Kong}

Correspondence to: Dr C C Mok, Department of Medicine, Tuen Mun Hospital, Tsing Chung Koon Road, New Territories, Hong Kong; ccmok2005@yahoo.com

Accepted 23 April 2005

\section{REFERENCES}

1 Hinchey J, Chaves C, Appignani B, Breen J, Pao L, Wang A, et al. A reversible posterior leukoencephalopathy syndrome. N Engl J Med 1996;334:494-500. 2 Primavera A, Audenino D, Mavilio N, Cocito L. Reversible posterior leucoencephalopathy syndrome in systemic lupus and vasculitis. Ann Rheum Dis 2001;60:534-7.

3 Yong PF, Hamour SM, Burns A. Reversible posterior leukoencephalopathy in a patient with systemic sclerosis/systemic lupus erythematosus overlap syndrome. Nephrol Dial Transplant 2003;18:2660-2.

\title{
Experimental infection with Plasmodium falciparum does not result in the induction of anticardiolipin antibodies in healthy volunteers
}

\author{
J Damoiseaux, A van der Ven, R Hermsen, D Telgt, M Roestenberg, J W Cohen Tervaert, \\ R Saverwein
}

A ntiphospholipid antibodies (aPL), particularly lupus anticoagulant or anticardiolipin antibodies (aCL), are diagnostic markers for the antiphospholipid syndrome, which is characterised by venous or arterial thrombosis or obstetric complications, or both. ${ }^{1}$ aPL may also occur in association with a multitude of infectious agents. Asherson and Cervera, while reviewing infection related aPL, mentioned malaria as one of the parasitic infections that has been associated with the presence of aPL. ${ }^{2}$ Indeed, two independent papers have described the high prevalence of aPL in patients with malaria. Jakobsen et al described the induction of IgM, but not IgG aPL during acute Plasmodium falciparum infection of Sudanese adults. ${ }^{3}$ The aPL were reactive with cardiolipin, phosphatidylinositol, and phosphatidylcholine. Facer and Agiostratidou examined adult patients of diverse ethnicity with uncomplicated non-severe malaria. ${ }^{4}$ They showed that $P$ falciparum and $P$ vivax infections are associated with the appearance of raised plasma levels of $\operatorname{IgM}$ and IgG aPL, and aCL were raised in over $75 \%$ of the patients with malaria. Patients with $P$ falciparum had high aPL IgG levels, exceeding the levels seen in positive controls. ${ }^{4}$ Because the observed association may lack a causal relation, we recently evaluated the induction of aPL in 10 healthy white volunteers upon infection with $P$ falciparum.
Anopheles stephensi mosquitoes were infected with the chloroquine sensitive NF54 isolate of $P$ falciparum at the insectary, as previously described. ${ }^{5}$ Sets of female mosquitoes were allowed to feed on the forearms for 10 minutes. Subsequent dissection was performed to confirm the presence of sporozoites in the mosquito salivary glands. If not present, the feed was repeated until successful. Volunteers were carefully monitored by assessing blood films twice daily. Upon microscopic detection of parasites, volunteers were immediately treated with a standard curative regimen of chloroquine.

Blood was sampled one day before infection and 1, 7, 10, 12 , and 20 days after infection. IgM and $\operatorname{IgG}$ aCL were analysed by commercial enzyme linked immunosorbent assay (ELISA; Pharmacia Diagnostics, Freiburg, Germany) in a serum dilution of $1: 100$. Results showed that all volunteers were negative for both IgM and IgG aCL before infection and remained negative for these antibodies during follow up. Thus, acute $P$ falciparum infection does not result in the induction of aCL.

Nevertheless, although there seems to be no causal relation between malaria and aCL, the coexistence of aPL may further complicate malarial infection. For instance, thrombocytopenia is often $(\sim 60 \%)$ seen in patients with malaria, and 
immune-mediated mechanisms have been suggested. ${ }^{67}$ Furthermore, in Gambian children with malaria the titres of aPL are significantly higher in severe than in mild malaria. ${ }^{3}$ However, a protective role of aPL has also been suggested. East African children with cerebral malaria had significantly lower titres of IgM anti-phosphatidylinositol antibodies than those with non-severe malaria. ${ }^{4}$ This is possibly explained by the neutralisation of the pathogenic properties of parasite derived phospholipid. ${ }^{8}$

Whatever the pathogenic role of aPL, our present results indicate that acute $P$ falciparum infection does not induce these antibodies in a white population. Whether aPL develop during chronic infections remains to be determined. Because genetic factors have been demonstrated to be associated with the prevalence of aPL, ${ }^{9}$ it can be expected that people originating from malaria endemic areas are more prone to the induction of aPL. Therefore, analysis of aPL upon experimental infection with $P$ falciparum in healthy volunteers from malaria endemic areas may further unravel the causal relation between malaria and aPL.

\section{Authors' affiliations}

J Damoiseaux, J W Cohen Tervaert, Department of Clinical and Experimental Immunology, University Hospital Maastricht, PO Box 5800, 6202 AZ Maastricht, the Netherlands

A van der Ven, D Telgt, Department of Internal Medicine, University Medical Centre Nijmegen, PO Box 9101, 6500 HB Nijmegen, the Netherlands

R Hermsen, M Roestenberg, R Saverwein, Department of Medical Microbiology, University Medical Centre Nijmegen, PO Box 9101, 6500 HB Nijmegen, the Netherlands
Competing interest statement: None of the authors have any competing interest.

Ethics approval: This study was approved by the medical ethics committee of the University Medical Centre Nijmegen.

Correspondence to: Dr J Damoiseaux, jdam@limm.azm.nl

Accepted 8 May 2005

\section{REFERENCES}

1 Wilson WA, Gharavi AE, Koike T, Lockshin MD, Branch DW, Piette JC, et al. International consensus statement on preliminary classification criteria for definite antiphospholipid syndrome: report of an international workshop. Arthritis Rheum 1999;42:1309-11.

2 Asherson RA, Cervera R. Antiphospholipid antibodies and infections. Ann Rheum Dis 2003;62:388-93.

3 Jakobsen PH, Morris-Jones SD, Hviid L, Theander TG, Hoier-Madsen M, Bayoumi RA, et al. Anti-phospholipid antibodies in patients with Plasmodium falciparum malaria. Immunology 1993;79:653-7.

4 Facer CA, Agiostratidou G. High levels of anti-phospholipid antibodies in uncomplicated and severe Plasmodium falciparum and in P. vivax malaria. Clin Exp Immunol 1994;95:304-9.

5 Hermsen CC, Vlas SJ de, Gemert GJA van, Telgt DSC, Verhage DF, Sauerwein RW. Testing vaccines in human experimental malaria: statistical analysis of parasitemia measured by a quantitative real-time polymerase chain reaction. Am J Trop Med Hyg 2004;71:196-201.

6 Kelton JG, Keystone J, Moore J, Denomme G, Tozman E, Glynn M, et al. Immune-mediated thrombocytopenia of malaria. J Clin Invest 1983;71:832-6.

7 Sorensen PG, Mickley H, Schmidt KG. Malaria-induced immune thrombocytopenia. Vox Sang 1984;47:68-72.

8 Daniel-Ribeiro CT, Zanini G. Autoimmunity and malaria: what are they doing together? Acta Trop 2000;76:205-21.

9 Domenico Sebastiani G, Minisola G, Galeazzi M. HLA class II alleles and genetic predisposition to the antiphospholipid syndrome. Autoimmun Rev 2003;2:387-94.

\title{
Population based studies of biological antirheumatic drug use in southern Sweden: comparison with pharmaceutical sales
}

\author{
P Geborek, E Nitelius, S Noltorp, H Petri, L Jacobsson, L Larsson, T Saxne, I Leden
}

Ann Rheum Dis 2005;64:1805-1807. doi: 10.1136/ard.2005.036715

$\mathrm{T}$ his study aimed at assessing the drug costs for biological treatments in a geographically defined area in southern Sweden (Scania province, population 1145 090, November 2002), and at identifying any geographical differences and changes with time in the overall use of these compounds. Also, we wanted to investigate the completeness of the registry held by the South Swedish Arthritis Treatment Group (SSATG). ${ }^{1}$ During the study period no economic prescribing restrictions existed for these drugs in the region. The Swedish social security system covers all prescribed drug costs exceeding SEK $1800(€ 170)$ a year to all patients in need, where need is based on their physician's judgment. Thus, the use of biological antirheumatic treatment was limited only by restricted drug availability and capacity of the administration facilities. Medical practice was, however, under strong influence by guidelines from the Swedish Rheumatological Association.

SSATG data were used to explore annual and regional relations, assessing the current and previous use of biological agents, prescription costs, and patient's diagnoses. The

figures were adjusted according to the census population registry during 2000-03. Owing to legal constraints, which do not allow direct data linkage between SSATG and prescription databases, SSATG derived annual theoretical costs and sales of pharmaceutical agents to outpatients during the period 2000-03 (public domain) were broken down according to the patient's district of residency as the unifying concept. To obtain an estimate of the costs per week of using the different drugs we assumed the annual drug dosage to be $2550 \mathrm{mg}$ etanercept, $2100 \mathrm{mg}$ infliximab, $1040 \mathrm{mg}$ adalimumab, and $36500 \mathrm{mg}$ anakinra, respectively. Year-specific pharmacy unit drug costs were used. In 2002 the resulting costs were SEK 144935 ( 1 SEK $=0.1 €$ ) for etanercept, SEK 108539 for infliximab, SEK 143377 for anakinra, and SEK 112895 for adalimumab. The estimated yearly consumption of etanercept and infliximab was based on a previous detailed health economic study, ${ }^{2}$ whereas for anakinra and adalimumab we used the dosage recommended by the manufacturers. Registry data was checked against an assumed disease prevalence of $0.5 \%$ of the adult population. ${ }^{3}$ 

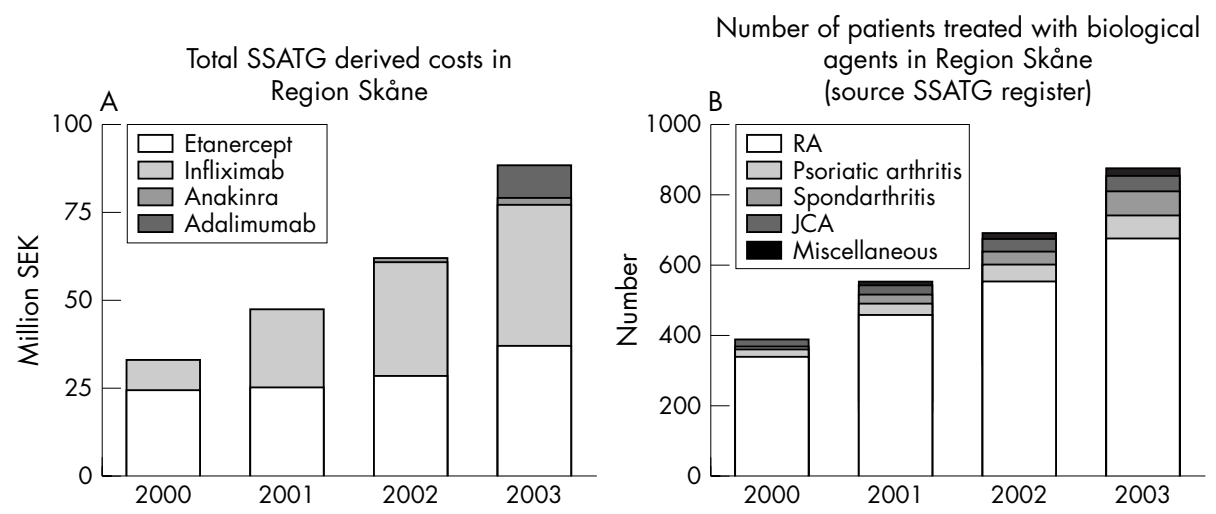

Figure 1 Total and drug related yearly biological drug costs (A) and number of patients treated with biological drugs related to the diagnosis (B) during 1999-2003 in Scania, derived from SSATG information.

Costs per head varied by a factor of 10 between residential districts, mostly because of low population numbers in some residential districts. However, when related to the five larger healthcare districts, twofold differences remained. The proportion of patients treated increased progressively and was about $14.9 \%$ of all patients with rheumatoid arthritis (RA) in 2003. The proportion of diagnoses other than RA increased from $13.1 \%$ to $22.7 \%$ during the study (fig 1). Pharmacy based and SSATG estimated cost ratios for all biological agents varied between 0.95 and 1.07 for the study years, but ratios for the individual drugs varied between 0.77 and 1.58. Concordance between pharmacy and SSATG cost figures increased with time (table 1), mostly explained by the increasing number of rheumatological centres joining the SSATG. The number of biological treatments started increased from 24 to 46 per 100000 inhabitants between 2000 and 2003 and the number of biological treatments withdrawn increased from 4 to 20 per 100 000 inhabitants. The proportion of new biological treatments in patients previously treated with a biological drug increased from $4 \%$ to $44 \%$ between 2000 and 2003 .

The regular overestimation of etanercept and underestimation of infliximab in SSATG costs suggests that the estimates have a systematic error. Several explanations can be offered, including annual pauses of longer than 1 week for etanercept, and prescription of infliximab for diagnoses other than those included in the SSATG registry. It can be estimated

Table 1 Outward pharmaceutical sales and SSATG derived sales in SEK for biological drugs during the period 2000-03 in Scania $(€ 1=9.05$ SEK, $\$ 1=$ SEK 8.5 SEK, May 2003)

\begin{tabular}{|c|c|c|c|c|c|}
\hline & 2000 & 2001 & 2002 & 2003 & $\begin{array}{l}\text { Sum } \\
2000-03\end{array}$ \\
\hline \multicolumn{6}{|l|}{ Pharmacy } \\
\hline Etanercept & 18983353 & 23385102 & 25493373 & 34371270 & 102233098 \\
\hline Infliximab & 13259906 & 27173845 & 37617778 & 43080718 & 121132247 \\
\hline Anakinra & 0 & 0 & 1384760 & 2623048 & 4007808 \\
\hline Adalimumab & 0 & 0 & 0 & 3999376 & 3999376 \\
\hline Total & 32243259 & 50558947 & 64495911 & 84074412 & 231372529 \\
\hline \multicolumn{6}{|l|}{ SSATG } \\
\hline Etanercept & 24772571 & 25384933 & 28525854 & 37028082 & 115711440 \\
\hline Infliximab & 8368944 & 21970848 & 32146426 & 40032834 & 102519052 \\
\hline Anakinra & 0 & 0 & 950435 & 2026440 & 2976875 \\
\hline Adalimumab & 0 & 0 & 0 & 4846806 & 4846806 \\
\hline Total & 33141515 & 47355781 & 61622715 & 83934162 & 226054173 \\
\hline \multicolumn{6}{|c|}{ Pharmacy/SSATG cost ratio } \\
\hline Etanercept & 0.77 & 0.92 & 0.89 & 0.93 & 0.88 \\
\hline Infliximab & 1.58 & 1.24 & 1.17 & 1.08 & 1.18 \\
\hline Anakinra & & & 1.46 & 1.29 & 1.35 \\
\hline Adalimumab & & & & 0.83 & 0.83 \\
\hline Total & 0.97 & 1.07 & 1.05 & 1.00 & 1.02 \\
\hline \multicolumn{6}{|c|}{ Proportion of adult population treated with biological agents (per 100000 inhabitants) } \\
\hline RA & 38.3 & 51.4 & 61.4 & 74.6 & \\
\hline Psoriatic arthritis & 2.3 & 3.6 & 5.2 & 7.3 & \\
\hline Other spondarthritis & 1.1 & 2.8 & 4.6 & 7.6 & \\
\hline JCA & 2.1 & 3.1 & 3.9 & 4.7 & \\
\hline Miscellaneous & 0.2 & 1.1 & 1.6 & 2.3 & \\
\hline Total & 44.0 & 62.1 & 76.6 & 96.5 & \\
\hline \multicolumn{6}{|c|}{ Proportion of patients with RA treated with biological agents (\% of estimated RA population) } \\
\hline & 7.7 & 10.3 & 12.3 & 14.9 & \\
\hline
\end{tabular}

For comparison the ratio between pharmaceutical and SSATG sales is also given. The proportion of patients for each diagnosis treated with biological agents as well as the relation (in \%) to the estimated total RA population in Scania $(0.5 \%$ of adult population) during the period 2000-03 according to the SSATG register. 
(table 1 ) that the SSATG includes $>90 \%$ of patients with arthritis currently treated with biological agents. This allows reliable continuous documentation of effects and potential side effects. Furthermore, a regional pharmacovigilance registry is also useful for assessing local differences in the use of the drugs and for evaluation of monitoring costs.

This study was supported by grants from Österlund and Kock Foundations, King Gustav V 80 year fund, and Reumatikerförbundet.

\section{Authors' affiliations}

P Geborek, L Larsson, T Saxne, Department of Rheumatology, Lund University Hospital, S-221 85 Lund, Sweden

E Nitelius, Department of Internal Medicine, Trelleborg Hospital, S-231 55 Trelleborg, Sweden

S Noltorp, Department of Internal Medicine, Helsingborg Hospital, S25187 Helsinborg, Sweden

H Petri, Department of Internal Medicine, Simrishamn Hospital, S-272

81 Simrishamn, Sweden
L Jacobsson, Department of Rheumatology, Malmö University Hospital, S-205 02 Malmö, Sweden

I Leden, Department of Internal Medicine, Kristianstad Hospital, S-291 85 Kristianstad, Sweden

Correspondence to: Dr P Geborek, Pierre.geborek@reum.lu.se

Accepted 14 April 2005

\section{REFERENCES}

1 Geborek P, Crnkic M, Petersson IF, Saxne T. Etanercept, infliximab and leflunomide in established rheumatoid arthritis. Clinical experience using a structured follow-up programme in southern Sweden. Ann Rheum Dis 2002;61:793-8.

2 Kobelt G, Eberhardt K, Geborek P. TNF-Inhibitors in the treatment of rheumatoid arthritis in clinical practice. costs and outcomes in a follow-up study of patients with rheumatoid arthritis treated with etanercept or infliximab in Southern Sweden. Ann Rheum Dis 2004;63:4-10.

3 Simonsson M, Bergman S, Jacobsson LT, Petersson IF, Svensson B. The prevalence of rheumatoid arthritis in Sweden. Scand J Rheumatol 1999;28:340-3.

\title{
Anti-cyclic citrullinated peptide antibodies in patients with rheumatoid arthritis treated with anti-tumour necrosis factor agents
}

\author{
A S Russell, W P Maksymowych, M de Silva
}

Ann Rheum Dis 2005;64:1807. doi: 10.1136/ard.2005.040436

D e Rycke et al pointed out the interesting discord between rheumatoid factor titre and the titre of anticyclic citrullinated peptide (anti-CCP) antibodies in their patients responding to infliximab plus methotrexate treatment. ${ }^{1}$

We have looked at 158 patients receiving either infliximab or etanercept plus methotrexate and treated for a slightly longer period over l year, all of whom, by definition, had responded with at least an ACR20, and in whom pretreatment serum samples were available.

We found essentially the same result for anti-CCP antibodies. Twenty four (15\%) serum samples were negative at the outset, one of these became strongly positive in the serum specimen after 1 year. Of those who were strongly positive, one became negative; otherwise the titres remained relatively stable. Whether this in any way reflects the observation that the extra-articular features of rheumatoid arthritis-nodules, pulmonary disease, etc-do not seem to respond to these therapeutic agents might be a suggestion worth considering.

\section{Authors' affiliations}

A S Russell, W P Maksymowych, M de Silva, University of Alberta, Edmonton T6G2S2, Canada

Correspondence to: Dr A S Russell, asr@ualberta.ca

Accepted 2 May 2005

\section{REFERENCE}

1 De Rycke L, Verhelst X, Kruithof E, Van den Bosche F, Hoffman IEA, Veys EM, et al. Rheumatoid factor, but not anti-cyclic citrullinated peptide antibodies, is modulated by infliximab treatment in rheumatoid arthritis. Ann Rheum Dis 2005;64:299-302. 